Article

\title{
Solid Phases Precipitating in Artificial Urine in the Absence and Presence of Bacteria Proteus mirabilis-A Contribution to the Understanding of Infectious Urinary Stone Formation
}

\author{
Jolanta Prywer ${ }^{1, *}$, Marcin Kozanecki ${ }^{2}$, Ewa Mielniczek-Brzóska ${ }^{3}$ and Agnieszka Torzewska ${ }^{4}$ \\ 1 Institute of Physics, Lodz University of Technology, ul. Wólczańska 219, 90-924 Łódź, Poland \\ 2 Department of Molecular Physics, Lodz University of Technology, ul. Żeromskiego 116, 90-924 Łódź, Poland; \\ marcin.kozanecki@p.lodz.pl \\ 3 Institute of Chemistry, Environment Protection and Biotechnology, Jan Długosz University of Częstochowa, \\ ul. Armii Krajowej 13/15, 42-200 Częstochowa, Poland; e.mielniczek@ajd.czest.pl \\ 4 Department of Biology of Bacteria, Faculty of Biology and Environmental Protection, University of Lodz, \\ ul. Banacha 12/16, 90-237 Łódź, Poland; agnieszka.torzewska@biol.uni.lodz.pl \\ * Correspondence: jolanta.prywer@p.lodz.pl; Tel.: +48-42-631-36-53
}

Received: 12 March 2018; Accepted: 6 April 2018; Published: 9 April 2018

\begin{abstract}
Magnesium ammonium phosphate hexahydrate, called struvite, is the dominant component of infectious urinary stones. In addition to struvite, infectious urinary stones include solid phases with poor crystallinity as well as amorphous matter. This article is devoted to the analysis of these solid phases, because they have not been characterized well until now. The solid phases tested were obtained from artificial urine in the absence and presence of Proteus mirabilis. The solid phases were characterized by different techniques (X-ray Diffraction, Energy Dispersive X-ray, Scanning Electron Microscopy, as well as Raman and Infrared Spectroscopies). According to the results these phases are carbonate apatite (CA), hydroxylapatite (HAP), amorphous calcium carbonate (ACC), amorphous calcium phosphate (ACP) and/or amorphous carbonated calcium phosphate (ACCP). Carbonate apatite and hydroxylapatite may occur in non-stoichiometric forms, i.e., various anions can be substituted for $\mathrm{CO}_{3}{ }^{2-}, \mathrm{OH}^{-}$, and $\mathrm{PO}_{4}{ }^{3-}$ groups in them. The non-stoichiometry of carbonate apatite and hydroxylapatite also implies a deficiency of calcium ions, i.e., calcium ions may be partially replaced by other cations. Experimental techniques and chemical speciation analysis demonstrate that the presence of magnesium influences the formation of CA and HAP.
\end{abstract}

Keywords: carbonate apatite; hydroxylapatite; amorphous calcium carbonate; amorphous calcium phosphate; amorphous calcium phosphate; amorphous carbonated calcium phosphate; amorphous precursors; infectious urinary stones

\section{Introduction}

A large number of people suffer from urinary stone problems [1,2]. There are several types of urinary stones that differ in composition and etiology. The most common type of urinary stone is composed of calcium oxalate and is caused by metabolic disorders that are often treatable.

The so-called infectious stones are a separate kind of urinary stones, whose formation is related to urinary tract infection [3,4]. The infection is a result of the activity of microorganisms producing urease, mainly those from Proteus species. Urease is a characteristic bacterial enzyme performing a catalytic function, i.e., the hydrolysis of urea $\left(\mathrm{H}_{2} \mathrm{~N}-\mathrm{CO}-\mathrm{NH}_{2}\right)$, which is normally present in the urine of a healthy person. The final products are carbamic acid $\left(\mathrm{H}_{2} \mathrm{~N}-\mathrm{COOH}\right)$ and ammonia $\left(\mathrm{NH}_{3}\right)$. 
The former hydrolyses spontaneously to another molecule of ammonia and carbonic acid $\left(\mathrm{H}_{2} \mathrm{CO}_{3}\right)$, according to the following reactions $[5,6]$ :

$$
\begin{gathered}
\mathrm{H}_{2} \mathrm{~N}-\mathrm{CO}-\mathrm{NH}_{2}+\mathrm{H}_{2} \mathrm{O} \stackrel{\text { urease }}{\rightarrow} \mathrm{H}_{2} \mathrm{~N}-\mathrm{COOH}+\mathrm{NH}_{3}, \\
\mathrm{H}_{2} \mathrm{~N}-\mathrm{COOH}+\mathrm{H}_{2} \mathrm{O} \rightarrow \mathrm{H}_{2} \mathrm{CO}_{3}+\mathrm{NH}_{3} .
\end{gathered}
$$

Further reactions increase the $\mathrm{pH}$ of urine and cause a significant increase in the concentration of $\mathrm{CO}_{3}{ }^{2-}$ and $\mathrm{NH}_{4}{ }^{+}$ions. The latter ion normally occurs in urine at low concentrations due to the presence of $\mathrm{NH}_{4} \mathrm{Cl}$. Ammonia ions together with calcium $\mathrm{Ca}^{2+}$ and magnesium $\mathrm{Mg}^{2+}$ cations present in the urine lead to the crystallization, at first, of carbonate apatite $\left(\mathrm{Ca}_{10}\left(\mathrm{PO}_{4}\right)_{6} \mathrm{CO}_{3} ; \mathrm{CA}\right)$ and then, of struvite (magnesium ammonium phosphate hexahydrate; $\mathrm{MgNH}_{4} \mathrm{PO}_{4} \cdot 6 \mathrm{H}_{2} \mathrm{O}$ ), according to the following reactions [6]:

$$
\begin{gathered}
\mathrm{CO}_{3}^{2-}+10 \mathrm{Ca}^{2+}+6 \mathrm{PO}_{4}^{3-} \stackrel{\mathrm{pH} \geq 6.8}{\rightarrow} \mathrm{Ca}_{10}\left(\mathrm{PO}_{4}\right)_{6} \mathrm{CO}_{3}(\downarrow), \\
\mathrm{Mg}^{2+}+\mathrm{NH}_{4}^{+}+\mathrm{PO}_{4}^{3-}+6 \mathrm{H}_{2} \mathrm{O} \stackrel{\mathrm{pH} \geq 7.2}{\rightarrow} \mathrm{MgNH}_{4} \mathrm{PO}_{4} \cdot 6 \mathrm{H}_{2} \mathrm{O}(\downarrow) .
\end{gathered}
$$

$\mathrm{CA}$ is a minor component of this kind of stones, but it precipitates first (at lower $\mathrm{pH}$ ). Struvite is the predominant crystalline component, but it crystallizes at higher $\mathrm{pH}(\mathrm{pH} \geq 7.2)$.

Some literature sources [7-10] mention that hydroxylapatite $\mathrm{Ca}_{10}\left(\mathrm{PO}_{4}\right)_{6}(\mathrm{OH})_{2}(\mathrm{HAP})$ is also present as a minor component of infectious urinary stones. Struvite mixed to various degrees with HAP and CA constitutes the so-called infectious urinary stones also called the struvite stones. It should be pointed out that HAP and CA belong to the family of apatites. Carbonate ions $\mathrm{CO}_{3}{ }^{2-}$ can substitute $\mathrm{OH}^{-}$groups in the structure of HAP, which is the A-type substitution that gives CA [11].

Generally, the investigation of the precipitations accompanying the infection of the urinary tract may be performed in artificial urine or in real stones removed from patient's bodies. In the experiments in artificial urine the infection is induced through the introduction of a suspension of bacteria to the artificial urine or is simulated in a chemical manner (e.g., Ref. [12]). In both cases, struvite and HAP and/or CA are formed, which may be further examined. The experiments performed in artificial urine and investigations of stones removed from patient's bodies have demonstrated that struvite appears in crystalline form, while HAP/CA shows poor crystallinity [7]. The studies have also revealed amorphous matter both in experiments in artificial urine and in the actual urinary stones [7]. However, although the apatites and other precipitates related to infectious urinary stones have been studied with different techniques for over 40 years, the exact nature of these solid phases is not well understood.

Over recent years we have published a series of articles concerning infectious urinary stones [12-18]. In these articles we considered struvite and CA as the main components of this kind of stones. However, we met with the objections that CA cannot be formed in artificial urine of the composition used in our study. It was also pointed out that CA may be in crystalline form only, not amorphous as we claimed in some of our articles [12-18]. Therefore, the first aim of this study was to obtain precipitates in artificial urine in the case of the presence of bacteria and in the case when the infection is mimicked in a chemical manner. The second and most important aim of the present study was also to characterize the obtained precipitates using different techniques, i.e., X-ray Diffraction (XRD), Energy Dispersive X-ray (EDX), Scanning Electron Microscopy (SEM), optical microscopy as well as Raman and Infrared (IR) Spectroscopies and to establish what kinds of precipitates are formed in the case of infectious urinary stones.

\section{Materials and Methods}

The artificial urine used in our experiments was made of the components listed in Table 1. This composition of artificial urine is widely accepted in the literature [19-21]. The artificial urine was prepared by dissolving chemicals (Sigma Aldrich, Darmstadt, Germany) of reagent-grade purity in distilled water. Then the solution of artificial urine was filtered through a membrane filter with pore 
size of $0.2 \mu \mathrm{m}$. The content of the mineral components in such artificial urine corresponds to the mean concentration found in a 24-h period in normal human urine. Tryptic soy broth (TSB) was used to stimulate bacterial growth. The initial $\mathrm{pH}$ of artificial urine was adjusted to a value of 5.8 .

Table 1. Artificial urine composition [20].

\begin{tabular}{cc}
\hline Substance & $(\mathrm{g} / \mathrm{L})$ \\
\hline $\mathrm{CaCl}_{2} \cdot 2 \mathrm{H}_{2}$ & 0.651 \\
$\mathrm{MgCl}_{2} \cdot 6 \mathrm{H}_{2} \mathrm{O}$ & 0.651 \\
$\mathrm{NaCl}$ & 4.6 \\
$\mathrm{Na}_{2} \mathrm{SO}_{4}$ & 2.3 \\
$\mathrm{Na}_{3} \mathrm{C}_{6} \mathrm{H}_{5} \mathrm{O}_{7}$ & 0.65 \\
$\mathrm{Na}_{2} \mathrm{C}_{2} \mathrm{O}_{4}$ & 0.023 \\
$\mathrm{KH}_{2} \mathrm{PO}_{4}$ & 2.8 \\
$\mathrm{KCl}$ & 1.6 \\
$\mathrm{NH}_{4} \mathrm{Cl}$ & 1.0 \\
$\mathrm{CO}\left(\mathrm{NH}_{2}\right)_{2}$ & 25.0 \\
$\mathrm{C}_{4} \mathrm{H}_{9} \mathrm{~N}_{3} \mathrm{O}_{2}$ & 1.1 \\
Tryptic soy broth & 10.0 \\
\hline
\end{tabular}

In this study two kinds of experiments were performed. In the first one, the precipitation of solid phases occurred without bacteria. In this case to mimic urease activity aqueous ammonia solution $(1.2 \mathrm{M})$ was successively added. Such an addition causes an increase in $\mathrm{pH}$ value, as it occurs in the actual urinary tract infection. The aqueous ammonia solution was added until $\mathrm{pH}$ reached the value 9.5. The reason why it is the highest value of $\mathrm{pH}$ is explained below. In the second kind of experiment the formation of solid phases occurred due to the presence of appropriate bacteria. The Proteus mirabilis (P. mirabilis) were used as these bacteria are the most often isolated from human urinary stones $(70 \%$ of all cases) [22,23]. Before the experiment of solid phase formation, the bacteria were maintained on a slant of tryptic soy agar overnight at $37^{\circ} \mathrm{C}$ and then suspended in artificial urine at the concentration of $5 \times 10^{5} \mathrm{CFU}$ per $\mathrm{mL}$ (CFU—colony forming unit). The presence of bacteria in artificial urine, strictly speaking the activity of bacterial enzyme-urease - causes an increase in $\mathrm{pH}$, as mentioned in the Introduction. The $\mathrm{pH}$ increases beginning from the initial value of 5.8 to 9.5. The $\mathrm{pH}$ equal to 9.5 is the highest value and is achieved after $8 \mathrm{~h}$ of incubation. The $\mathrm{pH}$ level is correlated with the bacteria viability, $\mathrm{pH}$ higher than 8 has a bacteriocidic effect. The $\mathrm{pH}$ of the artificial urine was monitored during the experiments using a digital pH-meter (Elmetron CPC-401) at an accuracy of 0.01 . The experiments in the absence as well as in the presence of bacteria were conducted under thermostated conditions at $37.0 \pm 0.5^{\circ} \mathrm{C}$. In the absence of bacteria the temperature was kept constant by circulating water from a constant temperature water bath; in the presence of bacteria the samples were incubated at $37^{\circ} \mathrm{C}$. The experiments were made at least in triplicate for the assessment of repeatability.

The aim of the present study was to examine HAP and/or CA or other solid phases that might appear in both cases, in the absence and the presence of P. mirabilis. The appearance of struvite in infectious urinary stones is well known and confirmed [24,25] and its presence is not controversial. However, the appearance of HAP and/or CA or other solid phases promote controversies. In this study the results of examination of HAP and/or CA or other solid phases which appear with struvite and without it are presented and discussed. Especially the examination of the solid phases appearing without struvite is very important and interesting. Crystalline struvite may disturb the examination of other solid phases. Therefore, we performed two kinds of experiments. The first one was performed in artificial urine of the composition presented in Table 1. In such a case in artificial urine, as a consequence of the activity of urease or the addition of aqueous ammonia solution, struvite and other solid phases appear (HAP and/or CA or other solid phases). In this kind of experiment struvite may disturb some measurements, but the advantage of this experiment is that the composition of artificial urine is not changed. The second kind of experiment was performed in artificial urine whose composition 
was changed. This change was such that magnesium chloride hexahydrate was not a component of prepared artificial urine. Such a change causes struvite not to crystallize, but other solid phases (HAP and/or CA) appear. This kind of experiment facilitates the examination of formed precipitations.

The experimental protocol used for precipitate formation in the presence of bacteria involved placing a $2 \mathrm{~mL}$ of $5 \times 10^{6} \mathrm{CFU} / \mathrm{mL}$ bacterial suspension in a dialysis sac $(12,000-14,000$ Molecular Weight Cut Off-MWCO; Serva) placed in a tube containing $50 \mathrm{~mL}$; of artificial urine (thus, the added bacterial suspension corresponds to $1 \times 10^{5}$ bacteria per $\mathrm{ml}$ of the whole sample). Isolation of the bacteria contained in the dialysis sac from the urine solution allowed sampling without the potential interference of bacteria whose chemical components could interfere in the interpretation and comparison of samples with and without bacteria. Experiments were performed at $37^{\circ} \mathrm{C}$.

The precipitates appearing during the experiments were taken at pHs equal to 7,8 , and 9 in order to check whether the composition of the precipitates depends on $\mathrm{pH}$. In order to separate the precipitates formed from artificial urine the samples were centrifuged (a centrifuge Eppendorf 5702, $12,000 \mathrm{rpm}$ for $5 \mathrm{~min}$ in the case of the absence of bacteria and Sigma 1-15, 12,000 rpm for $20 \mathrm{~min}$ in the case of the presence of bacteria). Then, the resultant precipitates were rinsed in distilled water three times and each time centrifuged. The so prepared precipitates were dried at room temperature for $24 \mathrm{~h}$ and examined directly after drying.

Prepared dry samples were examined using XRD, EDX, SEM, optical microscopy, Raman and IR Spectroscopies. XRD was done using an X'pert PRO MPD (PANalytical) diffractometer. A Cu K $\mathrm{K}_{\alpha}$ radiation monochromatized by nickel filter was applied. Measurements were done in the range of $2 \theta$ angles from $5^{\circ}$ to $90^{\circ}$. A continuous scan was used (step $0.0167^{\circ}$ ); the measurement time of one step was $25 \mathrm{~s}$. The X'pert High Score Plus (PANalytical, Almelo, The Netherlands) software was used for indexing peaks in the XRD pattern. The SEM micrographs were performed using a Vega 5135 MM-Tescan microscope (Tescan, Brno, Czech Republic) (Figure 1b,c) and FEI Quanta 200F microscope (ThermoFisher Scientific, Hillsboro, USA) (Figure 1d,e). EDX analysis was made using Oxford Instruments X-Max (50 mm²) (Oxford Instruments, Abingdon, United Kingdom). The samples from different stages of precipitation (collected at different $\mathrm{pHs}$ ) were observed using optical microscopy OptaTech MN800 (OptaTech, Warsaw, Poland) and Nikon Eclipse TE2000-S (Nikon Instruments Europe B.V., Amsterdam, The Netherlands).

A dispersive three-grating spectrometer T-64000 (Jobin-Yvon, Edison, NJ, USA) equipped with confocal microscope BX-40 (Olympus, Tokyo, Japan) was used to collect Raman spectra of the obtained precipitates. An Ar/Kr laser was used as an excitation light source. Different wavelengths generated by this laser were tested and finally the Ar $514.5 \mathrm{~nm}$ line was selected for systematic studies. In the applied configuration the spectral resolution was c.a. $0.5 \mathrm{~cm}^{-1}$. The laser light power on the sample surface did not exceed $2 \mathrm{~mW}$. The acquisition time was $120 \mathrm{~s}$ per point and two scans were averaged. All experiments were performed at room temperature, in back-scattering configuration using a long-distance objective with $50 \times$ magnification. Also, some attempts were made to perform measurements of the samples prepared in the presence of bacteria. Unfortunately, in spite of the use of a Fourier-Transform Raman system with the IR excitation source (Nd:YAG laser, $\lambda=1064 \mathrm{~nm}$ ), the re-emission (fluorescence) overlapped the Raman signal. This is a phenomenon quite often observed for biological material (microorganisms or the products of their activity) [26,27].

Absorption spectra in the middle IR region were collected at room temperature with the use of a Fourier Transform Infrared Spectrometer (A Thermo Scientific Nicolet, Waltham, MA, USA) equipped with an Attenuated Total Reflectance (ATR) accessory with diamond crystal. The spectral resolution was $2 \mathrm{~cm}^{-1}$ and 32 scans were averaged. Dry samples prepared according to the procedure described above were tested. The solid phases deposited on glass plates were tested also with the ATR accessory and the samples were held onto the diamond crystal by a special screw ensuring constant pressure. 


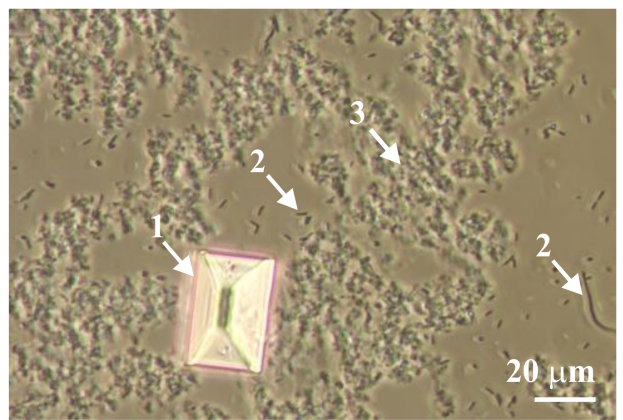

(a)

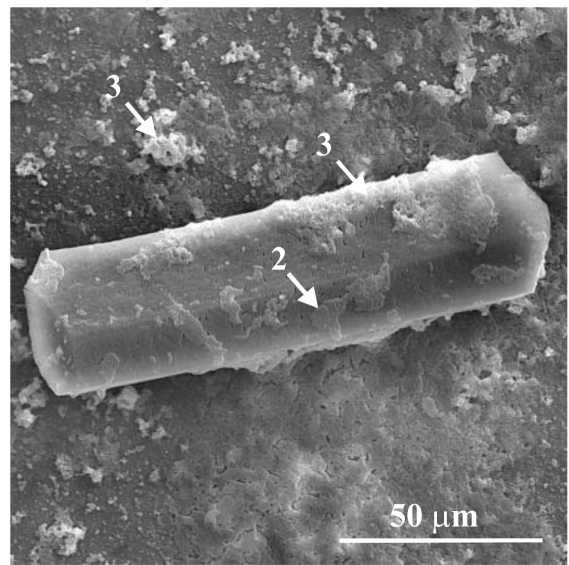

(b)

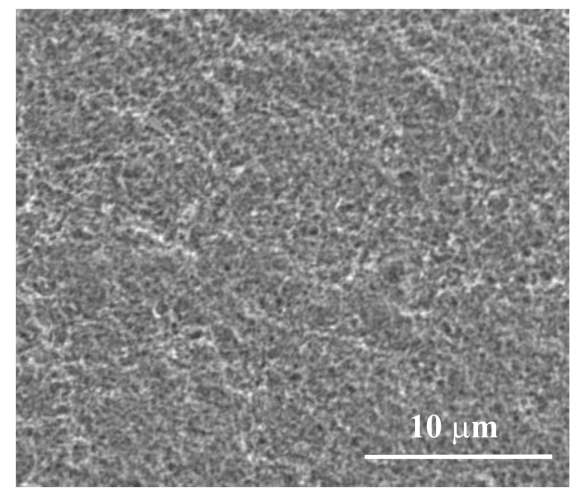

(d)

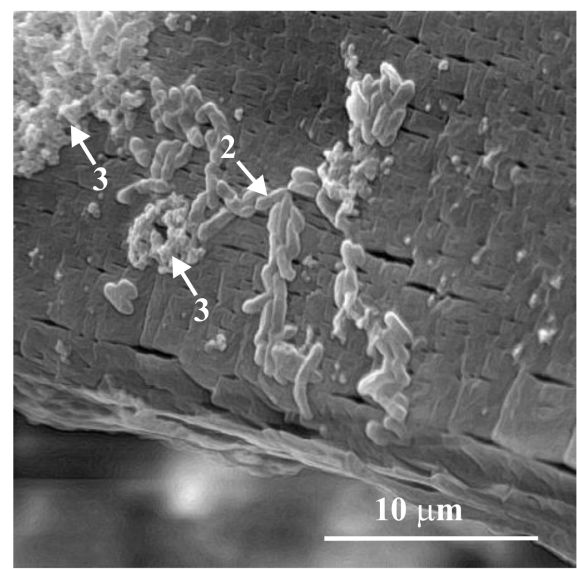

(c)

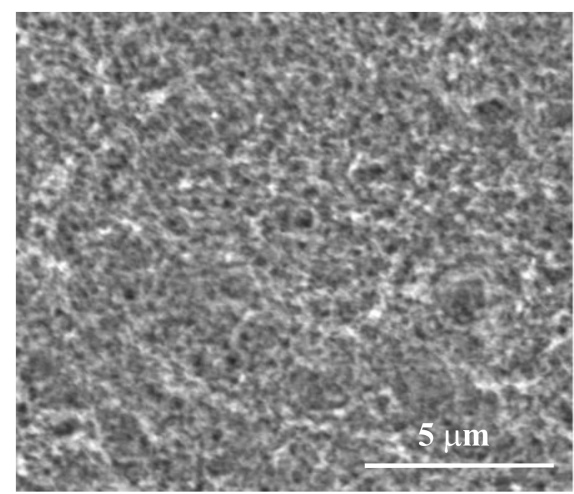

(e)

Figure 1. Considered precipitations (arrow 3) in the artificial urine of non-modified composition in the presence of bacteria (arrow 2); struvite is also seen (arrow 1) (a) optical microscope photograph; (b,c) scanning electron microscope (SEM) micrographs; (d,e) SEM micrographs showing the morphology of the considered precipitations formed in the artificial urine of modified composition (without magnesium chloride hexahydrate) and in the absence of bacteria (pH increased by aqueous ammonia solution) at $\mathrm{pH}=9$, in higher magnification.

Various vibrational spectroscopies are powerful, non-invasive tools for phase analysis in solid state. They consist of an analysis of interactions between electromagnetic waves with oscillating matter. In the case of Raman spectroscopy, the coherent electromagnetic wave (laser light) from the range of ultra-violet (UV), visible (Vis) or near infrared (NIR) is used to excite a sample and the inelastically scattered waves are analyzed. In absorption infrared (IR) spectroscopy the loss of radiation intensity when the ray passes through a sample is measured. Due to different selection rules (activity in Raman spectroscopy requires a change in system polarizability during oscillation, while in IR spectroscopy, the dipole momentum must change), depending on system symmetry, only part of the vibrational 
modes are visible in both Raman and IR spectra. Thus, to obtain a complete picture of the investigated systems Raman as well as IR spectroscopies were used.

Vibrational spectroscopy techniques allow confirmation of the results of $\mathrm{X}$-ray studies. Moreover, they offer additional information about the chemical structure of matter. This means, that they are able to distinguish different disorder phases, which was one of the most important goals of performed investigations. It is also worthy to note that as used in these studies the equipment does not require any special treatment of samples which is an additional advantage of the selected analytical methods.

In order to check the theoretical possibility of formation of HAP and CA in artificial urine a chemical speciation analysis was performed using computer code HySS [28]. This analysis allows determination of concentrations of $\mathrm{Ca}_{10}\left(\mathrm{PO}_{4}\right)_{6}(\mathrm{OH})_{2}$ and $\mathrm{Ca}_{10}\left(\mathrm{PO}_{4}\right)_{6} \mathrm{CO}_{3}$ complexes formed in artificial urine during the precipitation processes. On the basis of the stability constants and initial concentrations of various complexes, the concentrations of the $\mathrm{Ca}_{10}\left(\mathrm{PO}_{4}\right)_{6}(\mathrm{OH})_{2}$ and $\mathrm{Ca}_{10}\left(\mathrm{PO}_{4}\right)_{6} \mathrm{CO}_{3}$ complexes formed in artificial urine within the given $\mathrm{pH}$ range were calculated. The stability constants used in the HySS program were calculated with the aid of computer code EQUIL [29] or taken from literature [30-32]. The calculations were carried out for the temperature equal to $37^{\circ} \mathrm{C}$.

\section{General Characterization of Precipitates}

Struvite and CA and/or HAP are the main components of infectious urinary stones. Struvite with regard to its crystallinity is not controversial. The main subjects of the present study are HAP and/or CA whose precipitation is still not fully understood. HAP and/or CA arise in the course of infection in urinary tract caused by the bacterial urease activity. HAP and/or CA may also be formed when the infection is mimicked by aqueous ammonia solution. Figure 1 shows the obtained precipitates, struvite (arrow 1) and HAP and/or CA (arrow 3). Figure 1a presents the wet sample obtained in the presence of bacteria (arrows 2). This sample was obtained by taking a drop of solution of artificial urine with the precipitated solid phases, placement on a microscope slide and covering with a coverslip. The sample was observed with the aid of an optical microscope using transmitted light. The picture presents struvite in crystalline form (arrow 1) with well-defined crystallographic surfaces, bacteria (arrows 2) and the precipitate being the subject of our interest (arrow 3). There is no evidence that this precipitate is crystalline. Figure $1 \mathrm{~b}-\mathrm{e}$ shows SEM micrographs of the obtained precipitates. Figure $1 \mathrm{~b}$ shows the crystalline struvite, bacteria (arrow 2) with the precipitate being the subject of our interest (arrow 3). Figure 1c shows a similar struvite crystal like the one shown in Figure 1b, but at higher magnification. Here, one can see bacteria (arrow 2) with the precipitate being the subject of our interest (arrow 3). Both bacteria and the precipitate of interest are deposited on struvite. Struvite shows very characteristic structuration suggesting its porous nature. This issue is known and has been described in the literature $[33,34]$. Figure $1 \mathrm{~d}$,e shows the obtained precipitate in the absence of bacteria and in the case when the composition of artificial urine is modified (without magnesium chloride hexahydrate) so that no formation of struvite takes place; only the precipitate which is the subject of our interest occurs. On the basis of Figure 1 it can be concluded that the analyzed precipitate is not in a visible crystalline form. This precipitate forms aggregated particles without special organization and without visible features of crystallinity. However, it is not surprising. Biominerals often show a habit not typical of crystals, of not having the faces characteristic of crystals [35].

In order to find out more detailed information, the obtained precipitates which were the subject of our interest were examined using different techniques. The results are presented in the following Sections.

\section{XRD Characterization}

Experiments were performed for the precipitates obtained at $\mathrm{pH} 7,8$, and 9. The $\mathrm{pH}$ was gradually increased either by the addition of aqueous ammonia solution or as a result of the activity of urease as explained in Section 2. The experiments were performed either in the solution of artificial urine 
of the composition presented in Table 1 (non-modified) or in artificial urine of modified composition (without magnesium chloride hexahydrate).

\subsection{Modified Composition of Artificial Urine, pH Increase Induced by Aqueous Ammonia Solution}

The XRD results for this series are presented in Figure 2. In Figure 2a one can see broad diffraction peaks. The differences between the XRD patterns for different $\mathrm{pHs}$ are not visible. These broad peaks prove that the obtained precipitates show poor crystallinity. Figure $2 \mathrm{~b}$ presents one exemplary XRD pattern for the sample of $\mathrm{pH}=7$. It can be seen that the obtained peaks match well the peaks of hydroxylapatite $\mathrm{Ca}_{10}\left(\mathrm{PO}_{4}\right)_{6}(\mathrm{OH})_{2}$. It should be pointed out that the main peak of HAP is at $2 \theta$ of 31.9 degrees. However, one can see also a very broad band (indicated by the arrow) characteristic of disordered phases. This band means that part of the sample is amorphous.

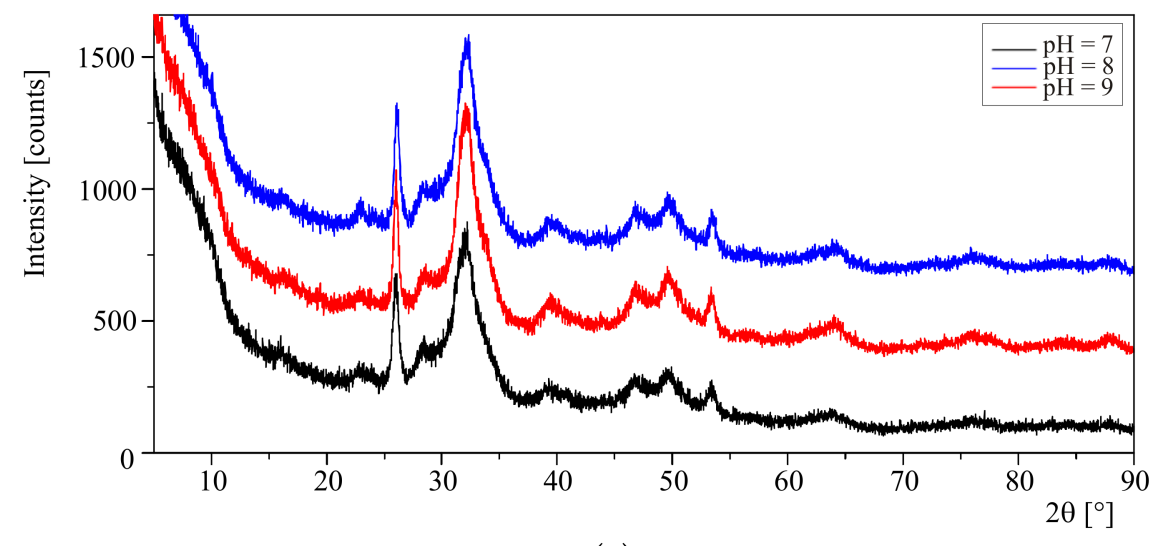

(a)

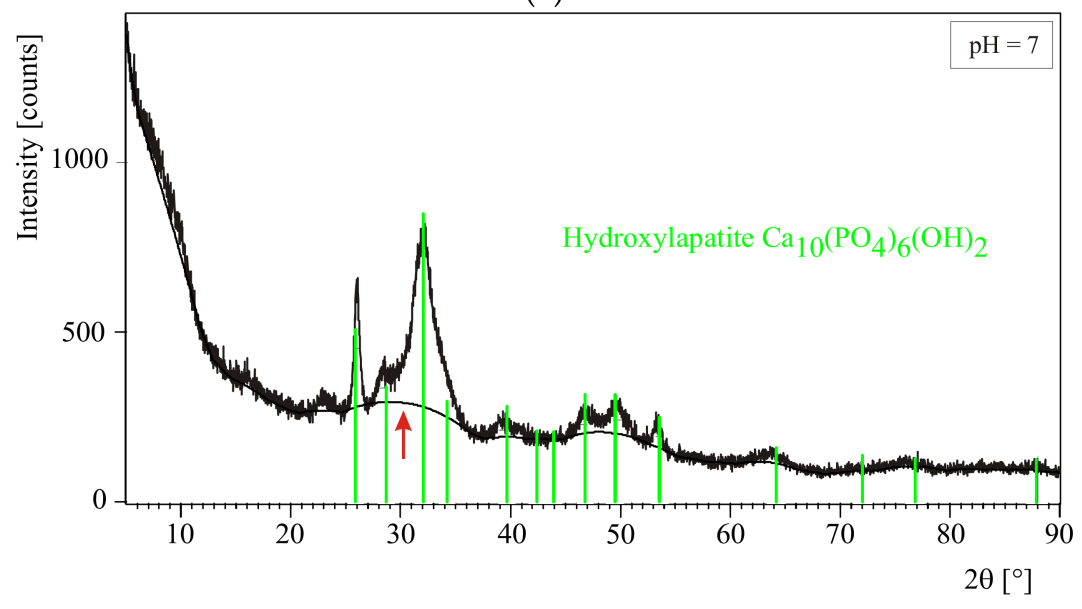

(b)

Figure 2. X-ray diffraction (XRD) patterns $(\mathbf{a}, \mathbf{b})$ of the samples in the case of modified composition of artificial urine (without magnesium chloride hexahydrate) and $\mathrm{pH}$ increased by aqueous ammonia solution, for different values of $\mathrm{pH}$. These spectra correspond to hydroxylapatite according to The International Centre for Diffraction Data (ICDD PDF-2 ver. 2009) card No. 00-001-1008. The arrow in (b) shows a broad halo which proves that some part of the sample is in amorphous form. The black line in (b) passing under the peaks is the measurement background.

\subsection{Non-Modified Composition of Artificial Urine, $p H$ Increase Induced by Aqueous Ammonia Solution}

The XRD results for this series are presented in Figure 3. Figure 3a shows XRD patterns for samples of $\mathrm{pH}=7$ and 8 . The diffractogram of the sample of $\mathrm{pH}=7$ is similar to the diffractograms recorded for the precipitates formed in artificial urine with modified composition. An amorphous 
halo and a pattern characteristic of HAP can be observed. For the sample of $\mathrm{pH}=8$ only two broad diffraction peaks can be seen. The main broad peak centered at around 32 degrees of $2 \theta$ suggests the presence of HAP, because the main peak of HAP is at 31.9 degrees of $2 \theta$. Figure $3 b$ shows the XRD pattern for the solid phases formed at $\mathrm{pH}=9$. Here, one can see sharp peaks which match the struvite peaks. To a certain degree the peaks also match the peaks of partially substituted hydroxylapatite i.e., $\mathrm{Ca}_{9} \mathrm{Na}_{0.5}\left(\mathrm{PO}_{4}\right)_{4.5}\left(\mathrm{CO}_{3}\right)_{1.5}(\mathrm{OH})_{2}$. The occurrence of this phase may indicate the substitution of $\mathrm{Na}^{+}$and $\mathrm{CO}_{3}{ }^{2-}$ for $\mathrm{Ca}^{2+}$ and $\mathrm{PO}_{4}{ }^{3-}$, respectively, in hydroxylapatite, $\mathrm{Ca}_{10}\left(\mathrm{PO}_{4}\right)_{6} \mathrm{OH}_{2}$. This type of hydroxylapatite substitution has already been described in Refs. [36,37]. However, it should be pointed out that in this case, a very characteristic halo (Figure $3 \mathrm{~b}$, arrow) is also seen indicating that part of the sample is in amorphous form.

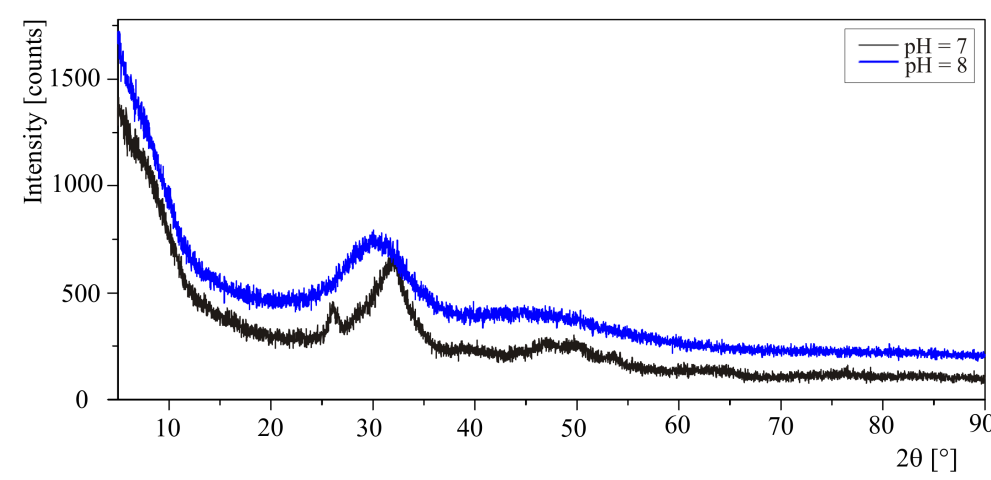

(a)

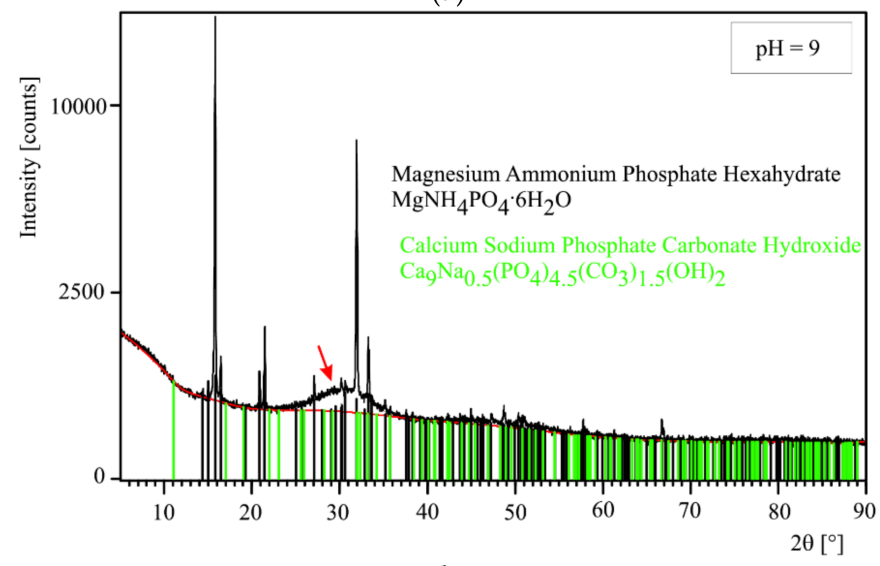

(b)

Figure 3. XRD patterns $(\mathbf{a}, \mathbf{b})$ of the samples in the case of non-modified composition of artificial urine and $\mathrm{pH}$ increased by aqueous ammonia solution, for different values of $\mathrm{pH}$. The spectra in (b) correspond to magnesium ammonium phosphate hexahydrate (struvite) and calcium sodium phosphate carbonate hydroxide according to The International Centre for Diffraction Data (ICDD PDF-2 ver. 2009) card No. 00-015-0762 and 01-089-7834, respectively. The arrow in (b) shows a broad halo which proves that some part of the sample is in amorphous form. The red line in (b) passing under the peaks is the measurement background.

\subsection{Modified Composition of Artificial Urine, $p H$ Increase Induced by the Presence of Bacteria}

The results for this series are presented in Figure 4. Figure 4a shows XRD patterns of the samples obtained at $\mathrm{pH}$ of 7,8 , and 9 . In the diffractogram of the sample for $\mathrm{pH}=7$ some peaks occur and they agree relatively well with those of calcium carbonate phosphate hydroxide $\mathrm{Ca}_{10}\left(\mathrm{PO}_{4}\right)_{4}\left(\mathrm{CO}_{3}\right)_{3}(\mathrm{OH})_{2}$, (Figure $4 \mathrm{~b}$ ), which belongs to the apatite group of minerals. In this case, the carbonate groups $\mathrm{CO}_{3}{ }^{2-}$ are substituted in place of $\mathrm{PO}_{4}{ }^{3-}$. It is interesting to note that in this case the amorphous halo around 30 degrees of $2 \theta$ is not visible (Figure $4 a$ ). This means that in this sample the crystalline 
material occurs only, without any amorphous phase. For the samples of $\mathrm{pH}$ equal to 8 and 9 the amorphous halo (arrows) with some broad and weak peaks (Figure 4a) may be distinguished in the diffractograms. These low-intense and wide peaks demonstrate that the crystallinity of the samples is poor. The adjustment to these peaks is shown in Figure $4 \mathrm{c}$ for the sample with $\mathrm{pH}=9$. It can be seen that these peaks match well the peaks typical of hydroxylapatite $\mathrm{Ca}_{10}\left(\mathrm{PO}_{4}\right)_{6}(\mathrm{OH})_{2}$. The broad halo observed for samples of $\mathrm{pH}$ of 8 and 9 (Figure 4a, arrows and Figure 4c, arrow) demonstrates that, apart from HAP, an amorphous phase is present in these samples.

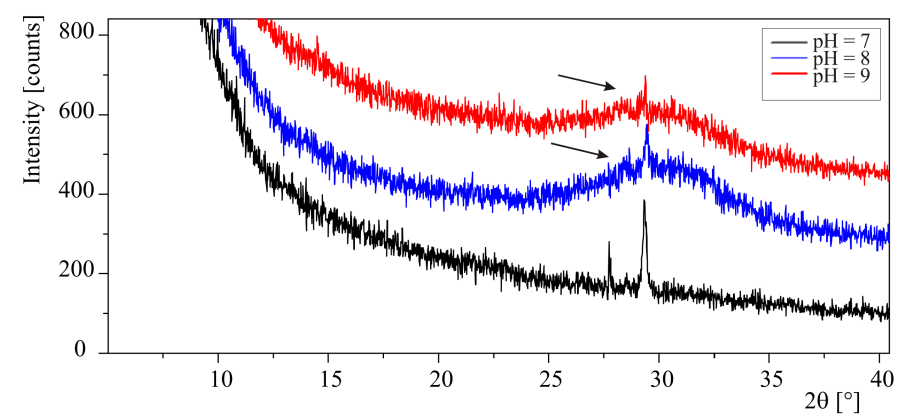

(a)

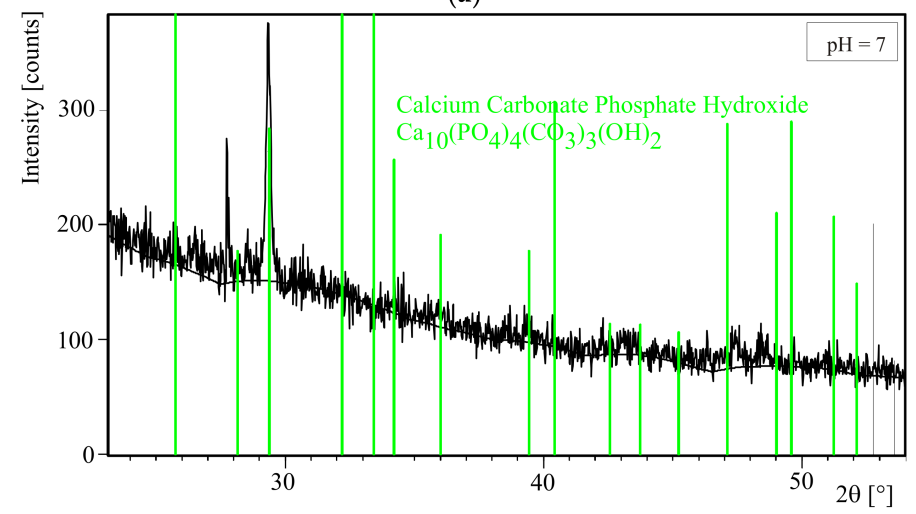

(b)

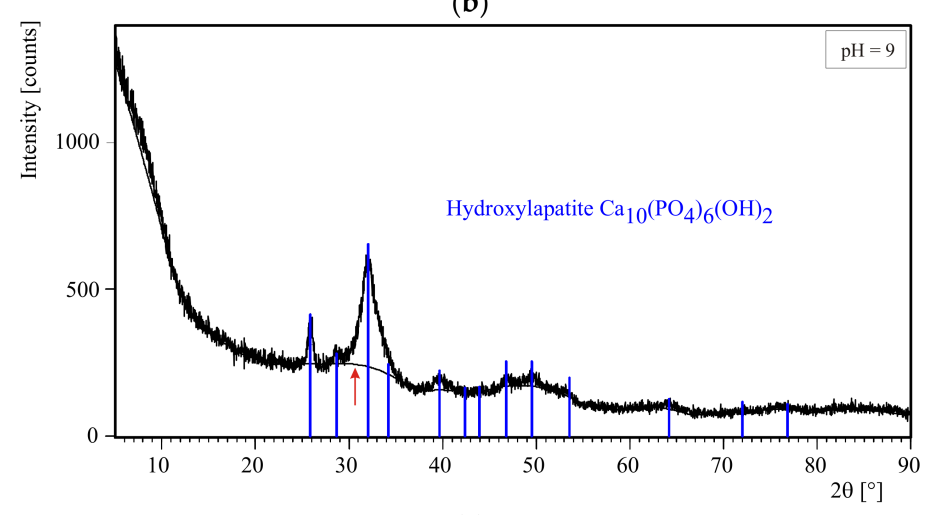

(c)

Figure 4. XRD patterns $(\mathbf{a}-\mathbf{c})$ of the samples in the case of modified composition of artificial urine (without magnesium chloride hexahydrate) and $\mathrm{pH}$ increase induced by the presence of Proteus mirabilis, for different values of $\mathrm{pH}$. The arrows in $(\mathbf{a}, \mathbf{c})$ show a broad halo which proves that part of the sample is in amorphous form. The observed diffraction peaks are related to calcium carbonate phosphate hydroxide (ICDD PDF-2 ver. 2009; card No. 00-019-0272), and hydroxylapatite (ICDD PDF-2 ver. 2009; card No. 00-001-1008). The black lines in (b,c) passing under the peaks are the measurement background. 


\subsection{Non-Modified Composition of Artificial Urine, pH Increase Induced by the Presence of Bacteria}

The results for this series are presented in Figure 5. On the basis of Figure 5a one may see that for the sample of $\mathrm{pH}=9$, the XRD pattern gives sharp and narrow peaks. Additionally, a broad halo (Figure $5 \mathrm{a}$, arrow) centered at around 32 degrees of $2 \theta$ is seen which indicates that the sample consists in part of amorphous phase.

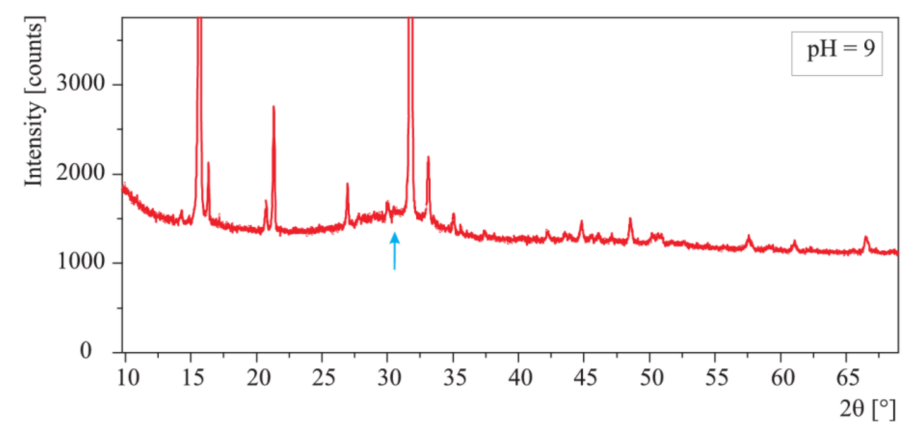

(a)

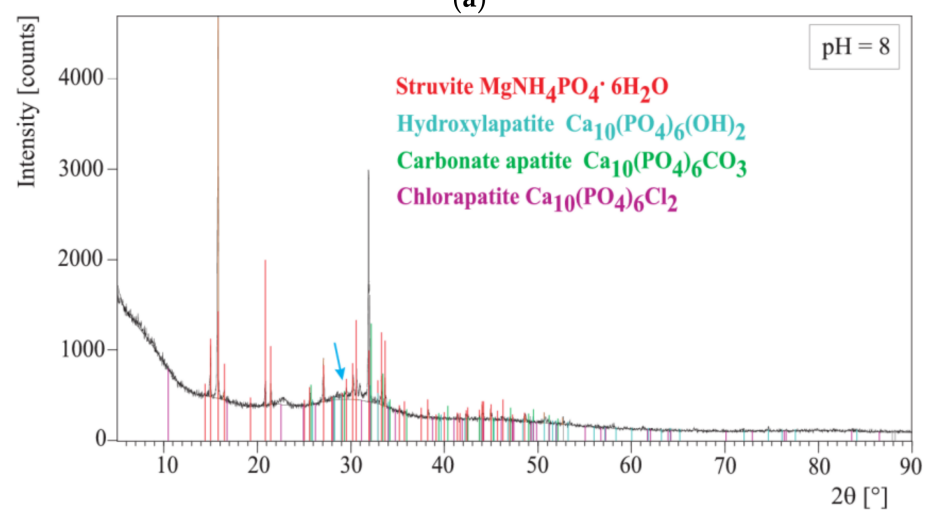

(b)

Figure 5. XRD patterns $(\mathbf{a}, \mathbf{b})$ of the samples in the case of non-modified composition of artificial urine (with magnesium chloride hexahydrate) and $\mathrm{pH}$ increase induced by the presence of Proteus mirabilis, for different values of $\mathrm{pH}$. The arrows in $(\mathbf{a}, \mathbf{b})$ show a broad halo proving that some part of the sample is in amorphous form. The observed diffraction peaks are related to magnesium ammonium phosphate hexahydrate (struvite) (ICDD PDF-2 ver. 2009) card No. 00-015-0762, hydroxylapatite (ICDD PDF-2 ver. 2009; card No. 00-001-1008), carbonate apatite (ICDD PDF-2 ver. 2009; card No. 00-012-0529), and chlorapatite (ICDD PDF-2 ver. 2009; card No. 00-012-0263). The black line in (b) passing under the peaks is the measurement background.

The exemplary best fit for the peaks recorded for the sample of $\mathrm{pH}=8$ is presented in Figure $5 \mathrm{~b}$. It is seen that the peaks match well those of struvite, hydroxylapatite (HAP), carbonate apatite (CA), and chlorapatite, $\mathrm{Ca}_{10}\left(\mathrm{PO}_{4}\right)_{6} \mathrm{Cl}_{2}$. The presence of chlorapatite agrees well with literature data. For example in Ref. [38] chlorapatite is found as a component of infectious urinary stones. The presence of chlorapatite indicates that $\mathrm{Cl}^{-}$is substituted in place of the $\mathrm{OH}^{-}$group in HAP.

\subsection{XRD Results—Discussion}

The results of XRD study presented in this article demonstrate that struvite is in crystalline form. It gives sharp, high, and narrow diffraction peaks, which proves its high crystallinity. High crystallinity of struvite is well-known from the literature [7] and does not arouse any controversy.

The main subjects of interest in the present study are the precipitates which are formed apart from struvite. As follows from the XRD results presented in Figures 2-5, generally CA and HAP are present in the considered samples. The simultaneous presence of HAP and CA is ascertained only in 
the presence of bacteria in artificial urine of non-modified composition. However, it is possible that the amount of CA in the case of the absence of bacteria may be just around the detection limit for XRD and it could therefore be undetected (usually, XRD has a detection limit of about $1 \%$ by volume; this means that if a compound is present below this level, no peaks above noise will be detected). Calcium phosphate carbonate hydroxide, $\mathrm{Ca}_{10}\left(\mathrm{PO}_{4}\right)_{4}\left(\mathrm{CO}_{3}\right)_{3}(\mathrm{OH})_{2}$, and chlorapatite, $\mathrm{Ca}_{10}\left(\mathrm{PO}_{4}\right)_{6} \mathrm{Cl}_{2}$, are also present in the samples. This result indicates that $\mathrm{CO}_{3}{ }^{2-}$ ion can substitute for the $\mathrm{PO}_{4}{ }^{3-}$ group in $\mathrm{HAP}$ and $\mathrm{Cl}^{-}$ion can substitute for the $\mathrm{CO}_{3}{ }^{2-}$ group in CA. The crystallinity of all these solid phases is poor as they give wide and low-intense diffraction peaks. Poor crystallinity of these phases is consistent with the literature data [7]. Moreover, the diffraction patterns of the samples demonstrate a broad halo at around 30 degrees of $2 \theta$, which proves the presence of amorphous matter. This observation is also in agreement with the literature [7]. This amorphous substance is most likely amorphous calcium phosphate (ACP) [39], amorphous calcium carbonate (ACP), or amorphous calcium carbonate phosphate (ACCP) [40].

In recent years, it has been shown in many articles [35,40-43] that some biominerals in the form of single crystals are not formed from the saturated solutions of their building ions, but from the precursor amorphous phase. Such transformation from the amorphous to the crystalline phase for $\mathrm{CaCO}_{3}$ is described, for example, by Weiner et al. [40]. It seems that in the case of biominerals, such a strategy is quite widespread. In Ref. [25] the transition of amorphous magnesium ammonium phosphate to the crystalline struvite in rat urinary stones induced to grow by Proteus mirabilis is described. These results represent in vivo studies. However, also in vitro formation of crystalline struvite preceded by the appearance of the amorphous phase has been observed [44]. The literature also describes the transformation of amorphous calcium phosphate (ACP) to hydroxylapatite (HAP) [39]. The results presented in this article indicate that there is also an amorphous phase in the samples tested. The cited literature results may suggest that also in the case of the present study, the amorphous phase appears at first, and then it is transformed into a weak crystalline phase (CA and/or HAP and/or chlorapatite) or highly crystalline struvite.

\section{Raman Analysis}

Raman spectroscopy was used as complementary to XRD and is a very useful phase analysis technique. It was used to confirm XRD data presented in the previous section and to supplement them with chemical structure information. It should be especially interesting in the case of amorphous phases, as XRD is not selective in this field.

Figure 6a presents Raman spectra of the samples obtained from artificial urine of modified composition (without magnesium chloride hexahydrate). The $\mathrm{pH}$ was increased by successive additions of aqueous ammonia solution (the series without the presence of bacteria). The Raman spectra shown in Figure 6a do not differ essentially from one another; they are almost identical for all pH values. The bands at 447, 579 [45], 962, 1029, 1047, and $1076 \mathrm{~cm}^{-1}$ [11] characteristic of HAP are the most intensive in these spectra. This finding implies that HAP is the dominant phase in the samples examined. The relatively broad FWHM (full width at half maximum) proved that the HAP crystalline phase is not perfect. The peak broadening may be assigned to amorphous phase formation or to the numerous defects in the crystal lattice. The broad Raman lines are also characteristic of nanocrystalline phases as the surface (defect from the crystallography point of view) to volume ratio increases with decreasing size of the crystals. The microcrystalline structure observed for the prepared samples (compare to Figure 1) suggests that the Raman peak broadening results rather from the amorphous phase presence, than from the crystal size reduction. This is in agreement also with our XRD results presented in Section 4.1, as in the diffractograms the amorphous phase assigned halo is present. The open question is the presence of carbonate apatite or carbonate ions in the samples. According to the literature, the Raman band assigned to $\mathrm{CO}_{3}{ }^{2-}$ ion appears at $1106 \mathrm{~cm}^{-1}$ [45] for A-type HAP $\left(\mathrm{CO}_{3}{ }^{2-}\right.$ is substituted in the structure of HAP at the $\mathrm{OH}^{-}$site). However, there is no band at this wavelength, while the line well visible at $1121 \mathrm{~cm}^{-1}$ may be assigned to the carbonate anion. The shift 
is probably due to the internal stresses induced in the sample, which is characteristic of polycrystalline as well semi-crystalline (mixture of amorphous and crystalline phases) structures. It is also worth noting the presence of $\mathrm{HPO}_{4}{ }^{2-}$ anions in the samples proved by the Raman line at $1005 \mathrm{~cm}^{-1}$ [45]. It is not surprising as the $\mathrm{pK}_{\mathrm{a} 2}$ for phosphoric $(\mathrm{V})$ acid is $1.2 \times 10^{-7}$. It means that at $\mathrm{pH}>7.21$ the concentration of $\mathrm{HPO}_{4}{ }^{2-}$ ions should be higher than that of $\mathrm{PO}_{4}{ }^{3-}$ ones. This is in agreement with the results presented in [17]. Here, it is shown (Figure 4 in Ref. [17]) that the concentration of $\mathrm{HPO}_{4}{ }^{2-}$ ion is higher than that of $\mathrm{PO}_{4}{ }^{3-}$ for $\mathrm{pH}$ higher than 7.21. The position of the band assigned to $\mathrm{HPO}_{4}{ }^{2-}$ suggests that the $\mathrm{HPO}_{4}{ }^{2-}$ ions substituted rather $\mathrm{PO}_{4}{ }^{3-}$ ions in the apatite lattice than formed separate crystals: brushite (dicalcium phosphate dihydrate, $\mathrm{CaHPO}_{4} \cdot 2 \mathrm{H}_{2} \mathrm{O}$, with the characteristic Raman line at $991 \mathrm{~cm}^{-1}$ [46]) or monetite (anhydrous dicalcium phosphate, $\mathrm{CaHPO}_{4}$ ) with the characteristic Raman line at $963 \mathrm{~cm}^{-1}$ [46]). The band at $3573 \mathrm{~cm}^{-1}$ is assigned to the $\mathrm{OH}$ stretching modes.
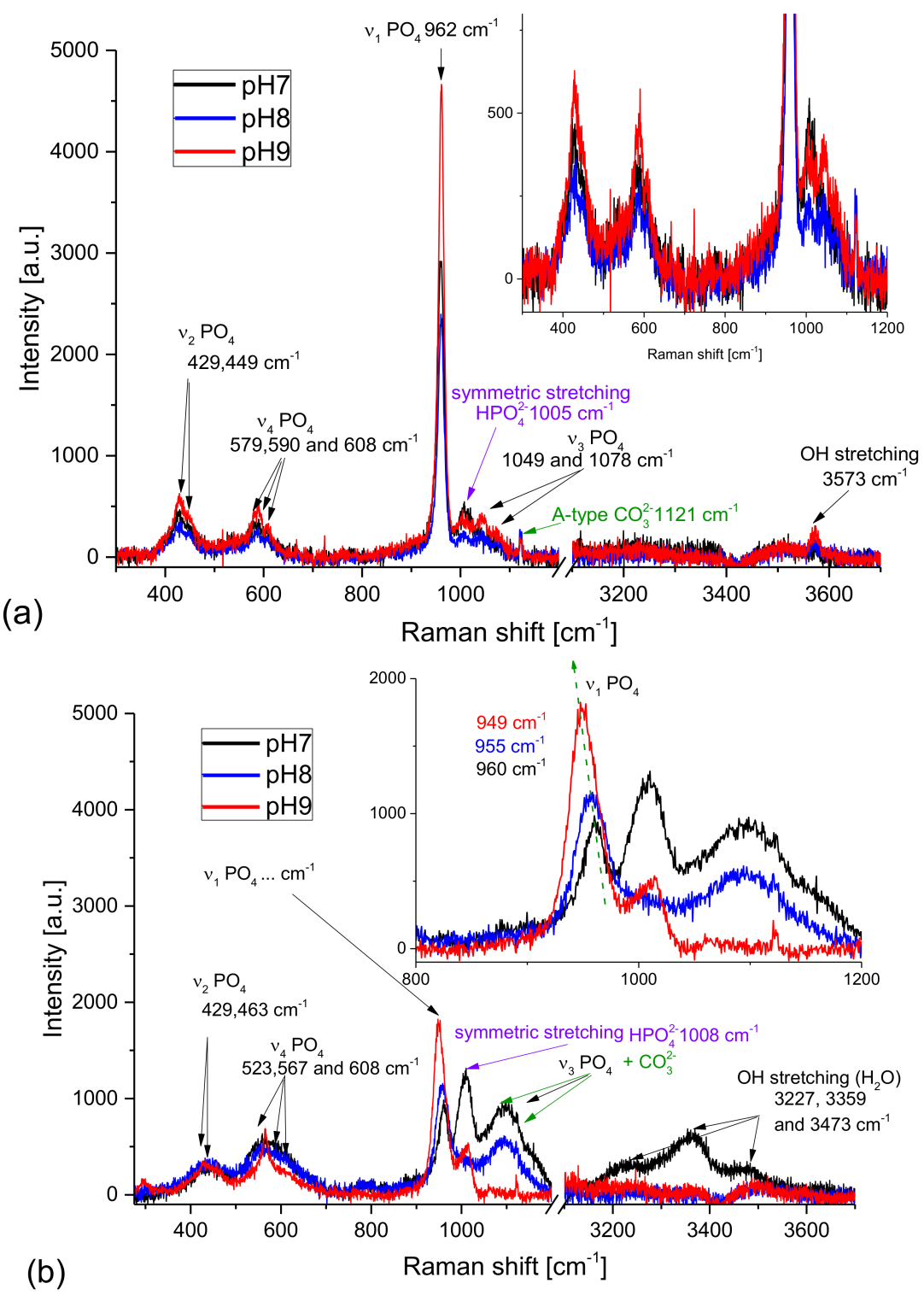

Figure 6. Raman spectra of the samples obtained in the absence of bacteria ( $\mathrm{pH}$ increased by aqueous ammonia solution) for (a) artificial urine of modified composition (without magnesium chloride hexahydrate); (b) artificial urine of non-modified composition. 
Figure $6 \mathrm{~b}$ presents the Raman spectra of the samples obtained from artificial urine of non-modified composition. The $\mathrm{pH}$ was increased by successive addition of aqueous ammonia solution (the series without the presence of bacteria). These spectra are essentially different from the previous ones recorded for the samples obtained from artificial urine of modified composition. All bands assigned to $\mathrm{PO}_{4}$ tetrahedra overlap with the standard-bands of HAP, however, their FWHMs are significantly broader than those of the samples obtained from the modified artificial urine. It strongly suggests that the amorphous phase of HAP dominates in the samples (especially in the precipitates formed at $\mathrm{pH}$ $=8$ ). For the sample of $\mathrm{pH}=7$, a strong line characteristic of $\mathrm{HPO}_{4}{ }^{2-}$ ions appears. However, it is necessary to remember that the presence of $\mathrm{Mg}^{2+}$ cations in the reacting mixture opens new pathways for many chemical reactions (sedimentations, substitutions, etc.) influencing the environment of the reaction. Moreover, the solubilities of magnesium phosphate and calcium phosphate are significantly different. Taking into account that the forming precipitates may still react as the equilibrium state is not reached immediately, it is reasonable to suppose that the solid phases with $\mathrm{HPO}_{4}{ }^{2-}$ can be formed. The number and diversity of reaction pathways which may be taking place makes it impossible to give a simple answer to the question of the mechanisms of formation of different solid phases. Moreover, the precipitation composed of different solid phases can change the $\mathrm{pH}$ in the system and shift the meta-stable equilibrium being a result of co-existence of many various species (solids, ions, water, non-ionized salts etc.). Further studies, especially kinetics ones, should be probably useful to explain more precisely the mechanism of formation of various phases in the urine environment.

The solid phase precipitated at $\mathrm{pH}=7$ is strongly hydrated as a relatively strong complex band between 3100 and 3600 is visible with the maxima at c.a. 3230,3360 , and $3475 \mathrm{~cm}^{-1}$. For the sample obtained at $\mathrm{pH}=8$ the water is practically absent. The amorphous character of the sample is proved by both: the broad lines of $\mathrm{PO}_{4}{ }^{3-}$ modes and also by the broad line characteristic of the $\mathrm{OH}$ stretching vibrations $\left(3570 \mathrm{~cm}^{-1}\right)$.

It is also worth noting that the bands assigned to $\mathrm{PO}_{4}$ are the highest and the narrowest for the sample precipitated at the highest $\mathrm{pH}$. It means that the crystallinity of this sample is the highest. Additionally, the band at about $1120 \mathrm{~cm}^{-1}$ characteristic of A-type $\mathrm{CO}_{3}{ }^{2-}$ is present. The maximum of the $v_{1} \mathrm{PO}_{4}$ band shifts toward lower frequencies with increasing $\mathrm{pH}$ (Figure $6 \mathrm{~b}$, inset). This is probably due to the substitution of $\mathrm{Ca}^{2+}$ anions by $\mathrm{Mg}^{2+}$ and $\mathrm{NH}_{4}{ }^{+}$cations as the characteristic maxima for apatite and struvite are at 962 and $949 \mathrm{~cm}^{-1}$ respectively. However, the presence of the $1100 \mathrm{~cm}^{-1}$ line characteristic of A-type $\mathrm{CO}_{3}{ }^{2-}$ and a relatively strong line at $1006 \mathrm{~cm}^{-1}$ prove that the struvite-like structures are accompanied by other phases: carbonates and various apatites containing both $\mathrm{PO}_{4}{ }^{3-}$ and $\mathrm{HPO}_{4}{ }^{2-}$ anions. The broad bands related to $v_{2}$ and $v_{4} \mathrm{PO}_{4}$ modes show that the sample is partially amorphous. Also, the broad line corresponding to the $\mathrm{OH}$ stretching vibrations suggests that the hydroxylapatite is formed and its crystallinity is low.

Concluding, the highest amount of ACP and ACCP is found in the sample prepared at the lowest $\mathrm{pH}$ of 7 . This means that the amount of carbonates/carbonate apatite decreases with increasing $\mathrm{pH}$. The sample at the highest $\mathrm{pH}$ used contains a mixture of struvite and crystalline as well amorphous phosphate and carbonate structures (HAP, ACP, ACCP). For all samples the Raman line characteristic of $\mathrm{HPO}_{4}{ }^{2-}$ was also detected. Probably this ion plays an important role in formation of various apatite, hydroxylapatite and carbonated apatite structures as well as struvite formation in the urine environment. This observation throws new light on the formation of these phases and may explain why the $\mathrm{pH}$ has such a strong influence on the precipitation process.

\section{IR Analysis}

The precipitates were also examined using Fourier-Transform Infrared (FTIR) spectroscopy. This technique is sensitive to polar groups and compounds such as carbonyl $(C=O)$ groups or water. Thus, it is especially useful to study carbonates as well as the water content in precipitated phases.

The spectra, normalized to the most intensive line, recorded for dry samples obtained in the absence of bacteria are presented in Figure 7. The spectra of the samples obtained from artificial urine 
of modified composition (magnesium chloride hexahydrate not added) match well (Figure 7a) the standard HAP spectrum taken from the RRUFF ${ }^{\mathrm{TM}}$ Database [46]. It is worth emphasizing that the spectra of the precipitated solid phases show broad bands in the frequency region $1500-1800 \mathrm{~cm}^{-1}$, which are not present for standard HAP. These peaks are characteristic of the $\mathrm{CO}_{3}{ }^{2-}$ ions and testify to the presence of carbonates; they may indicate the presence of carbonate apatite. One can also see a very broad band with a maximum at $3300-3400 \mathrm{~cm}^{-1}$ which is characteristic of the $\mathrm{OH}$ stretching vibrations. It should be noted that both carbonate and hydroxyl group absorption bands are broad, which is typical of disordered phases. Probably, the presence of carbonate anions that substituted the phosphate or hydroxyl ones, leads to formation of partially amorphous phases. The inset in Figure 7a shows higher magnification of the region between 800 and $1200 \mathrm{~cm}^{-1}$ with the main band (mode $v_{1}$ of $\mathrm{PO}_{4}$ ) of HAP at $1020 \mathrm{~cm}^{-1}$. As follows from the inset, the band in the spectra of the examined samples matches well that appearing in the standard HAP spectrum; there is no displacement, however for higher $\mathrm{pH}$ (8 and 9) a low frequency shoulder occurs, which may be assigned to the partial substitution of calcium ions by other cations $[36,37]$.

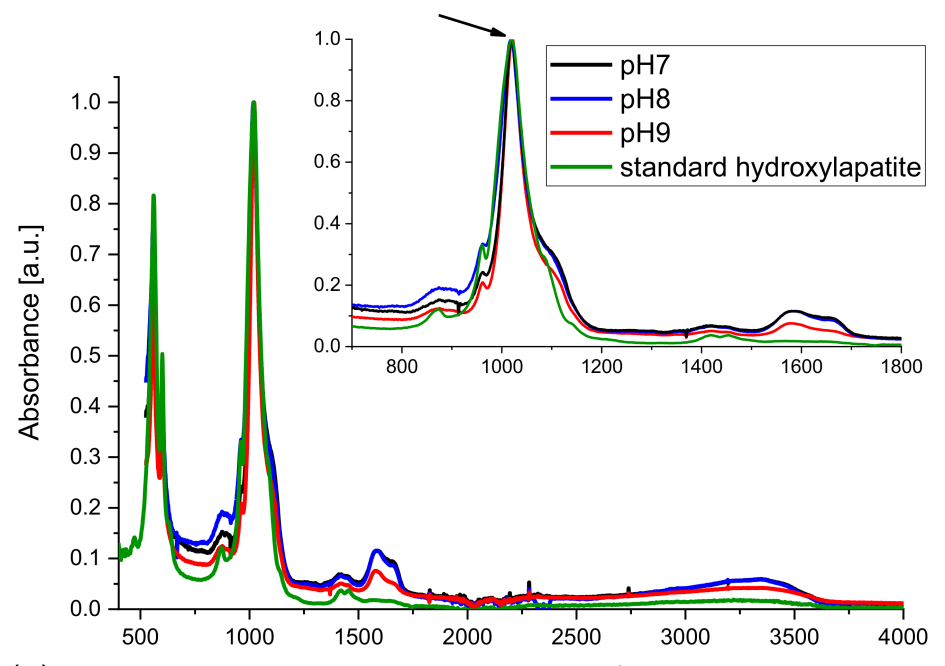

(a)

Wavenumber $\left[\mathrm{cm}^{-1}\right]$

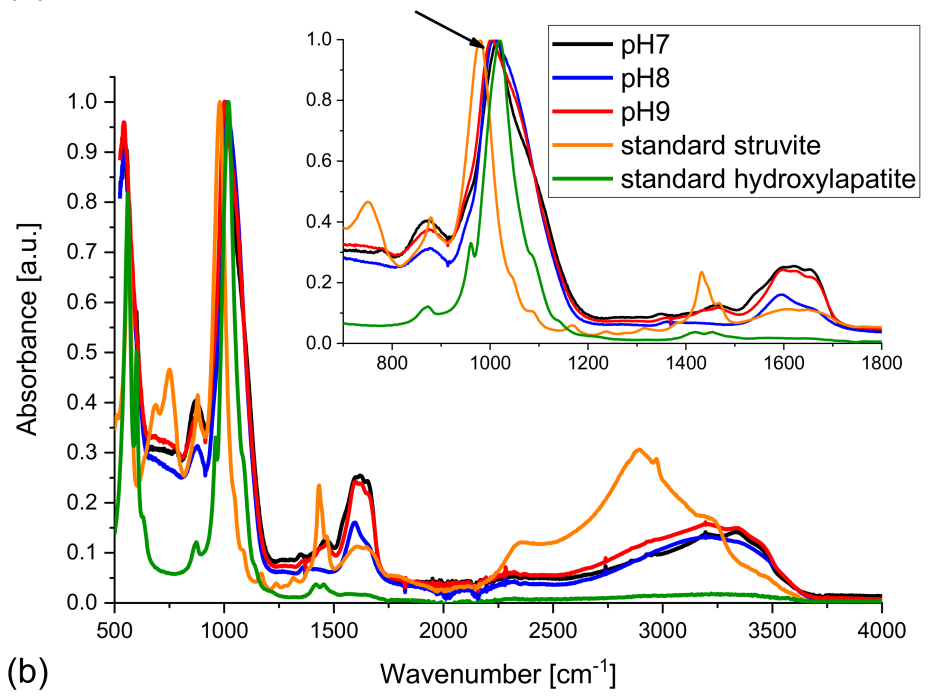

Figure 7. Infrared spectra of the samples obtained in the absence of bacteria ( $\mathrm{pH}$ increased by aqueous ammonia solution) in the artificial urine of (a) modified composition (without magnesium chloride hexahydrate); (b) non-modified composition. 
The IR spectra of the samples obtained from the artificial urine of normal composition of artificial urine (with magnesium chloride hexahydrate) were also measured. In such samples the presence of struvite is expected besides carbonates/carbonate apatite and HAP. Therefore, in Figure $7 \mathrm{~b}$ the spectra of standard HAP and standard struvite are added. A comparison of the obtained experimental spectra with those of standard HAP and struvite reveals that the experimentally obtained solid phases may be a mixture of struvite, HAP, and carbonates/carbonate apatite. Let us focus on the peaks at $1020 \mathrm{~cm}^{-1}$ characteristic of standard HAP and $980 \mathrm{~cm}^{-1}$ characteristic of standard struvite. According to Figure $7 \mathrm{~b}$ (inset), the peak in the spectrum of the sample at $\mathrm{pH}=7$ coincides well with the peak in the spectrum of standard HAP. However, it is shifted towards lower wavenumbers with increasing $\mathrm{pH}$ (Figure $\mathrm{7b}$ ). It should be noted that with increasing $\mathrm{pH}$ struvite starts to crystallize. In compliance with Equation (4) struvite starts to crystallize for $\mathrm{pH} \geq 7.2$. This means that for $\mathrm{pH}$ of 7 struvite is not expected to be formed. Therefore, the main peak in the spectrum of the sample at $\mathrm{pH}=7$ matches well that recorded for standard HAP. In the spectrum of the sample at $\mathrm{pH}=8$ the peak is slightly shifted towards smaller frequencies. In other words, it is shifted towards the position of the peak characteristic of standard struvite. The reason for such a shift is that with increasing $\mathrm{pH}$ more and more struvite appears. For $\mathrm{pH}=9$ when the quantity of struvite is the highest, this shift is the largest (Figure $7 \mathrm{~b}$, inset). This result may suggest that the samples obtained experimentally are mixture of HAP and struvite, which is in agreement with the Raman experiments. The quantity of struvite increases with $\mathrm{pH}$. In Figure $7 \mathrm{~b}$ one also sees peaks at 1590 and $1650 \mathrm{~cm}^{-1}$ characteristic of the presence of $\mathrm{CO}_{3}{ }^{2-}$. It means that besides HAP and struvite, the sample also contains carbonates. Because none of the other peaks is changed, it is highly probable that it is carbonate apatite.

Figure 8 presents the FTIR spectra of the samples formed in the presence of bacteria, normalized to the maximum intensity. Figure 8 a presents the IR spectra of the samples obtained in the case of modified composition of artificial urine (magnesium chloride hexahydrate not added). The main peak of standard HAP at $1020 \mathrm{~cm}^{-1}$ matches well the peaks of the samples examined. There is no displacement observed (Figure 8a, inset, arrow). There are also peaks at 1590 and $1650 \mathrm{~cm}^{-1}$ characteristic of the presence of carbonates, $\mathrm{CO}_{3}{ }^{2-}$. With increasing $\mathrm{pH}$, these peaks become smaller. This fact confirms that at the smallest $\mathrm{pH}$ of 7 the highest amount of carbonates must be formed. All experiments were performed in water environment as the broad band with a maximum at $3250 \mathrm{~cm}^{-1}$ is visible. The lower FWHM of the bands and some changes in the intensity of the lines characteristic of carbonates suggest that the sample at $\mathrm{pH}=9$ is partly crystallized, most probably containing hydroxylapatite (or apatite) and carbonate apatite.

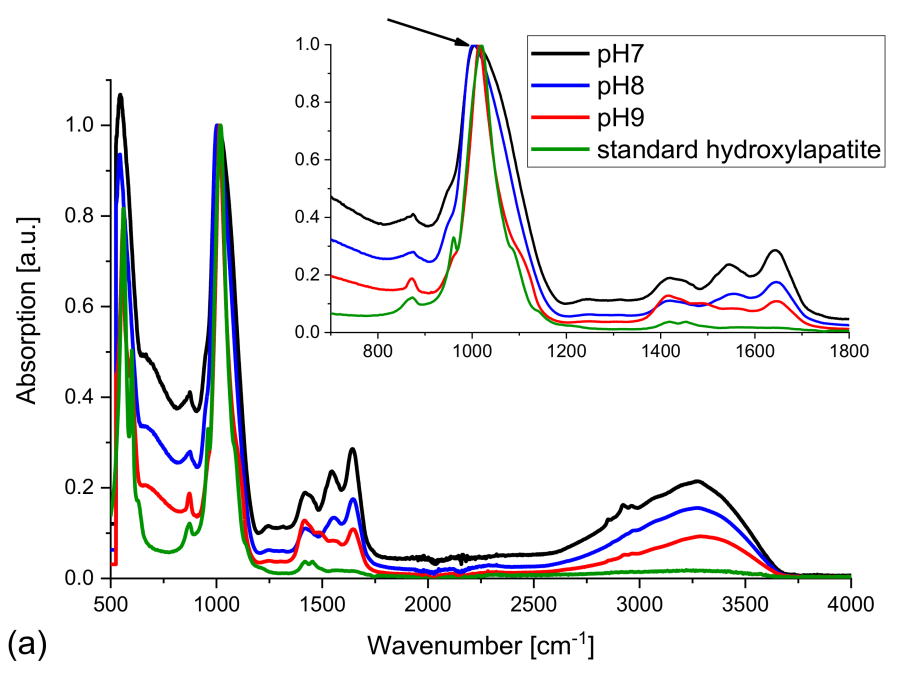

Figure 8. Cont. 


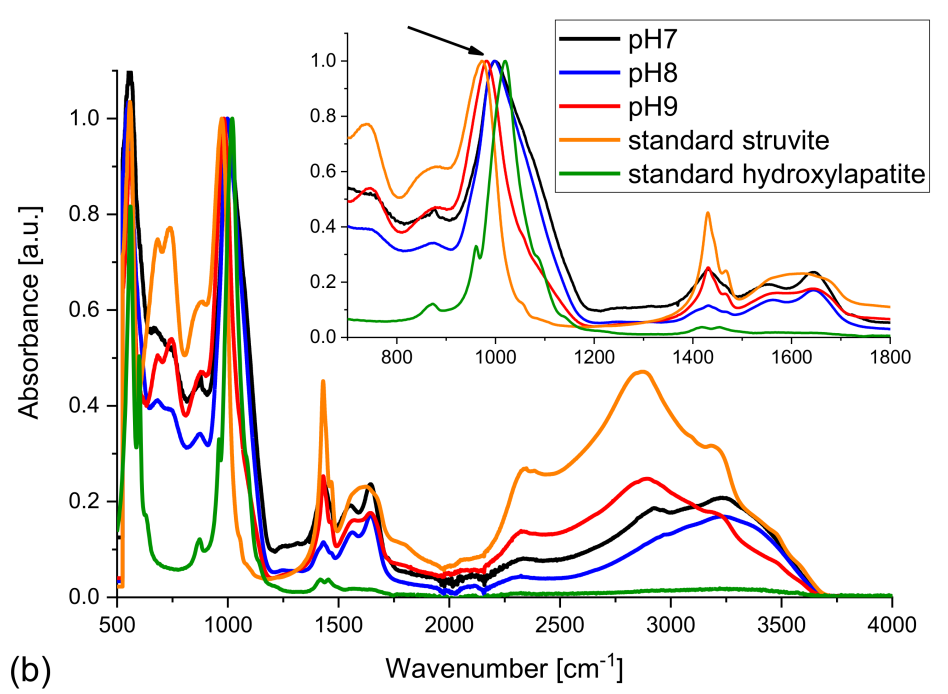

Figure 8. Infrared spectra of samples obtained in the presence of bacteria (increase in $\mathrm{pH}$ induced by the activity of bacteria) in the artificial urine of (a) modified composition (without magnesium chloride hexahydrate); (b) non-modified composition.

The situation is a little bit different in the case of samples obtained from the artificial urine of normal composition (with magnesium chloride hexahydrate); Figure 8b. Here one can see that the peak for $1020 \mathrm{~cm}^{-1}$ characteristic of standard HAP is shifted towards smaller frequencies with increasing $\mathrm{pH}$ (Figure $8 \mathrm{~b}$, inset, arrow). This shift can be explained by the appearance of struvite for $\mathrm{pH}$ higher than 7.2. The displacement of this peak is well visible in the inset of Figure $8 \mathrm{~b}$. In other words, the peak is shifted towards the peak characteristic of struvite. One can also see the peaks characteristic of $\mathrm{CO}_{3}{ }^{2-}$. This proves the presence of carbonates in the sample. It means that at $\mathrm{pH}=9, \mathrm{HAP}$, struvite, and carbonate phases co-exist, which is consistent with the results of previous Raman investigation. Taking into account that the positions of the peaks characteristic of HAP are not changed, it may be suggested that carbonate appears in the form of carbonate apatite. Santos and Clayton have shown that the vibrational bands of phosphorous ions in apatites shift with changes in the carbonate content [47].

Summarizing, the vibrational spectra of the samples precipitated in the artificial urine of modified composition of artificial urine (magnesium chloride hexahydrate not added) are almost the same for all tested $\mathrm{pHs}$. There are no essential differences with increasing $\mathrm{pH}$. In the case of normal composition of artificial urine the differences between spectra for different $\mathrm{pH}$ are notable. Carbonates/carbonate apatite appears first, at $\mathrm{pH}=7$ and its amount decreases with increasing $\mathrm{pH}$. Such a tendency is observed especially in the case of the presence of bacteria. With increasing $\mathrm{pH}$ the amount of HAP increases. Additionally, in the samples precipitated in artificial urine of normal composition, struvite is detected along with the phases containing $\mathrm{HPO}_{4}{ }^{2-}$ ions.

\section{Chemical Speciation Analysis}

In order to check the theoretical possibility of formation of HAP and/or CA in artificial urine, a chemical speciation analysis was performed using HySS [28] and EQUIL [29] computer codes. The ways of calculating the molar or percentage concentrations of various complexes in modified and non-modified artificial urine with the use of this computer software has already been presented in detail in earlier papers $[16,17]$. The starting point when using the HySS software is an introduction of the initial molar concentrations of all the components of urine (Table 1) [16,17] and the values of stability constants of the complexes forming in urine $[16,17]$. The EQUIL program makes it possible to calculate stability constants for most complexes at a temperature of $37^{\circ} \mathrm{C}$ while the values of $-\log \beta$ stability constants of the complexes which are taken into account in the analysis have been already published $[16,17]$. However, in this study, apart from the aforementioned complexes $[16,17]$ an 
additional assumption is made that hydroxylapatite complexes are formed in urine and their stability constant is $-\log \beta=38.97$ [30]. Such an approach permits determination of the molar and percentage concentrations of carbonate apatite and hydroxylapatite complexes, and also the range of $\mathrm{pH}$ in which they are formed.

The results obtained of such a speciation analysis are presented in Figure 9. Figure 9a presents the percentage content of $\mathrm{Ca}_{10}\left(\mathrm{PO}_{4}\right)_{6} \mathrm{CO}_{3}\left(\mathrm{CA}\right.$ complex) and $\mathrm{Ca}_{10}\left(\mathrm{PO}_{4}\right)_{6}(\mathrm{OH})_{2}$ (HAP complex) complexes depending on the $\mathrm{pH}$ of the artificial urine of non-modified composition. As follows from the data presented in Figure 9a, a sudden increase in the concentration of $\mathrm{Ca}_{10}\left(\mathrm{PO}_{4}\right)_{6} \mathrm{CO}_{3}$ complex is observed at $\mathrm{pH}$ 7.3. Then, with increasing $\mathrm{pH}$, the concentration of this complex increases and reaches a maximum at $\mathrm{pH}$ 8.4. From the data presented in Figure 9a it can be inferred that starting from $\mathrm{pH} 7.8$, $\mathrm{Ca}_{10}\left(\mathrm{PO}_{4}\right)_{6}(\mathrm{OH})_{2}$ complex begins to form. With increasing $\mathrm{pH}$, its concentration gradually increases, not reaching the state of saturation. The amount of CA formed is greater only for $\mathrm{pH}$ lower than 8.8. For $\mathrm{pH} 8.8$, the amounts of CA and HAP formed are the same. For $\mathrm{pH}$ higher than 8.8 the amount of HAP systematically increases and for $\mathrm{pH}$ higher than 9.1 the amount of HAP exceeds the amount of CA. By comparing the maximum values achieved in the $\mathrm{pH}$ range up to 10, one can conclude that the maximum amount of CA complex formed is significantly lower than that of the HAP complex. Assuming the amount of HAP complex at $\mathrm{pH}=10$ as $100 \%$, the maximum amount of CA complex is only $54 \%$ (Figure 9 a, right vertical axis). It is also worth noting that the CA complex is formed earlier (at lower $\mathrm{pH}$ ) than the HAP complex. CA complex begins to form at $\mathrm{pH} 7.3$ while HAP complex at $\mathrm{pH}$ 7.8. This conclusion is compatible with the results of Raman and FTIR investigation presented in paragraphs 5 and 6 . For the sake of recollection, it was found that CA is formed before HAP.

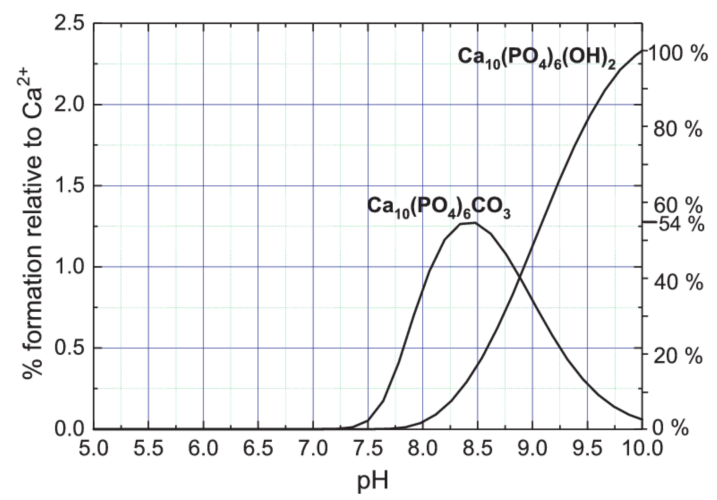

(a)

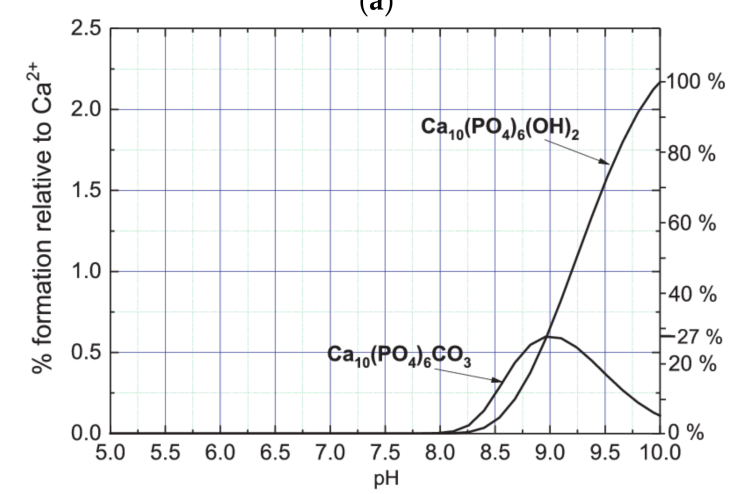

(b)

Figure 9. Percentage contents of $\mathrm{Ca}_{10}\left(\mathrm{PO}_{4}\right)_{6} \mathrm{CO}_{3}$ and $\mathrm{Ca}_{10}\left(\mathrm{PO}_{4}\right)_{6}(\mathrm{OH})_{2}$ complexes versus $\mathrm{pH}$ of the artificial urine of (a) non-modified and (b) modified composition. These percentage contents are given with respect to the initial concentration of $\mathrm{Ca}^{2+}$ ion. 
Figure $9 \mathrm{~b}$ presents the percentage content of $\mathrm{Ca}_{10}\left(\mathrm{PO}_{4}\right)_{6} \mathrm{CO}_{3}(\mathrm{CA}$ complex $)$ and $\mathrm{Ca}_{10}\left(\mathrm{PO}_{4}\right)_{6}(\mathrm{OH})_{2}$ (HAP complex) complexes depending on the $\mathrm{pH}$ of the artificial urine of modified composition (without magnesium chloride hexahydrate). As follows from this figure, the formation of both CA and HAP complexes is shifted towards higher $\mathrm{pH}$ as compared to the case of non-modified urine. CA complex starts forming from $\mathrm{pH} 8.1$ and HAP from $\mathrm{pH}$ 8.2. In addition, the amount of CA complex produced is considerably lower compared to non-modified urine. In the case of non-modified composition of artificial urine the maximum percentage content of CA complex relative to $\mathrm{Ca}^{2+}$ is on a level of $1.25 \%$ (Figure $9 \mathrm{a}$ ), while in the case of modified composition of artificial urine on a level of $0.65 \%$ only (Figure 9b). In the case of modified composition of artificial urine the relation between the maximum amounts of CA and HAP complexes is also different to that in the case of non-modified artificial urine. In the case of modified composition of artificial urine, assuming that the content of $\mathrm{HAP}$ at $\mathrm{pH}=10$ is $100 \%$, the maximum amount of CA complex is only $27 \%$ (right vertical axis). According to these results, in the case of non-modified urine, the amount of forming CA is much higher. This observation may suggest that the appearance of solid phases with carbonate $\left(\mathrm{CO}_{3}{ }^{2-}\right)$ requires the presence of magnesium. It is in agreement with literature data, for example in Refs. [7,48-51] it is reported that magnesium affects the formation of HAP. The results obtained in this work suggest that this may also be the case for CA. In addition, our results suggest that the presence of magnesium (non-modified urine) is responsible for the formation of both HAP and CA at lower $\mathrm{pH}$. Accurate determination of the effect of magnesium on the formation of $\mathrm{CA}$ and HAP requires analysis of chemical complexes formed in the urine in the presence of $\mathrm{Mg}$ and without $\mathrm{Mg}$ and chemical equilibria between them. However, this issue goes beyond the scope of the presented work.

The formation of CA in artificial urine runs according to Equation (3). Let us analyze what could be the reaction for HAP formation. In the urine of non-modified composition the synthesis of hydroxylapatite begins from $\mathrm{pH}$ 7.8. As shown in Ref. [17], in the $\mathrm{pH}$ range in which hydroxylapatite can be formed, calcium ions $\mathrm{Ca}^{2+}$ are present as free ions and in a form bounded in various complexes including such dominating complexes as $\mathrm{CaSO}_{4}, \mathrm{CaHPO}_{4}, \mathrm{CaCit}^{-}, \mathrm{CaPO}_{4}{ }^{-}$or $\mathrm{CaOH}^{-}$. Additionally, the phosphate groups within the $\mathrm{pH}$ range from 7 to 10 are present mainly in the form of $\mathrm{HPO}_{4}{ }^{2-}$ complexes [17], and when the $\mathrm{pH}>10$ they occur as $\mathrm{PO}_{4}{ }^{3-}$ anions [17]. These particular ions and complexes can become potential substrates for hydroxylapatite forming in the urine. Finally, the following reactions of hydroxylapatite formation can be proposed:

$$
\begin{gathered}
10 \mathrm{Ca}^{2+}+\mathrm{HPO}_{4}{ }^{2-}+2 \mathrm{H}_{2} \mathrm{O} \rightarrow \mathrm{Ca}_{10}\left(\mathrm{PO}_{4}\right)_{6}(\mathrm{OH})_{2}(\downarrow)+8 \mathrm{H}^{+} \\
6 \mathrm{CaHPO}_{4}+4 \mathrm{Ca}^{2+}+2 \mathrm{H}_{2} \mathrm{O} \rightarrow \mathrm{Ca}_{10}\left(\mathrm{PO}_{4}\right)_{6}(\mathrm{OH})_{2}(\downarrow)+8 \mathrm{H}^{+} \\
10 \mathrm{CaCit}^{-}+6 \mathrm{PO}_{4}{ }^{3-}+2 \mathrm{OH}^{-} \rightarrow \mathrm{Ca}_{10}\left(\mathrm{PO}_{4}\right)_{6}(\mathrm{OH})_{2}(\downarrow)+10 \mathrm{Cit}^{3-} \\
6 \mathrm{CaPO}_{4}{ }^{-}+4 \mathrm{CaOH}^{-} \rightarrow \mathrm{Ca}_{10}\left(\mathrm{PO}_{4}\right)_{6}(\mathrm{OH})_{2}(\downarrow)+2 \mathrm{OH}^{-}
\end{gathered}
$$

where the abbreviation $\mathrm{Cit}$ in the names of complexes stands for citrate group, $\mathrm{C}_{6} \mathrm{H}_{5} \mathrm{O}_{7}$.

\section{EDX Analysis}

From the analysis carried out so far it appears that CA and HAP are present in the analyzed precipitates. At the same time the research shows that in artificial urine non-stoichiometric $\mathrm{CA}$ and HAP can form, in which $\mathrm{Ca}^{2+}$ ions are replaced by $\mathrm{Na}^{+}$, and $\mathrm{OH}^{-}$and $/$or $\mathrm{CO}_{3}{ }^{2-}$ groups by $\mathrm{Cl}^{-}$ions. In order to check the atomic composition and the percentage of elements of the precipitate formed in artificial urine we performed EDX measurements. The tested samples were obtained in artificial urine of modified composition at $\mathrm{pH}$ of 9 . The examined samples are shown in Figure 1d,e. The obtained results are presented in Table 2 (experimental results). The experimental results (see Table 2) are mean values from several measurements. At the beginning it should be noted that the amount of carbon is overestimated for two reasons. Firstly, the samples were tested on a carbon substrate; and secondly, the collimator of the device is made of carbon which can give an additional signal. 
Table 2. Results of energy dispersive $\mathrm{X}$-ray (EDX) analysis for the sample obtained at $\mathrm{pH}=9$ (experimental results) and theoretical calculations based on stoichiometry (Cases 1-4).

\begin{tabular}{cccccc}
\hline \multirow{2}{*}{ Element } & \multicolumn{5}{c}{ Weight (\%) } \\
\cline { 2 - 6 } & \multirow{2}{*}{ Experimental Results (Mass Fraction of Elements \%) } & \multicolumn{4}{c}{ Theoretical Results } \\
\cline { 3 - 6 } & & Case 1 & Case 2 & Case 3 & Case 4 \\
\hline C & 9.78 & 0.590 & 0.583 & 0.386 & 0.557 \\
O & 40.06 & 41.664 & 41.187 & 39.585 & 41.131 \\
P & 18.87 & 18.263 & 18.053 & 17.915 & 18.110 \\
Ca & 30.90 & 39.384 & 31.146 & 30.907 & 31.244 \\
C & 0.39 & - & - & 2.278 & 0.329 \\
Na & 0.0 & - & 8.933 & 8.865 & 8.535 \\
H & - & 0.099 & 0.098 & 0.065 & 0.094 \\
Total & 100 & 100 & 100 & 100 & 100 \\
\hline
\end{tabular}

In order to determine which chemical compounds can form a precipitate of the specific atomic composition, theoretical calculations were performed. The calculation procedure includes: (1) calculation of the starting composition of the sample on the basis of the above mentioned experimental results; (2) the calculation of percentage content of each element in the starting composition; and (3) comparison of the results with those obtained by the use of the EDX method. The results of calculations are presented in Table 2; cases 1-4. In case 1 it is assumed that $\mathrm{Ca}_{10}\left(\mathrm{PO}_{4}\right)_{6}(\mathrm{OH})_{2}(\mathrm{HAP})$ and $\mathrm{Ca}_{10}\left(\mathrm{PO}_{4}\right)_{6} \mathrm{CO}_{3}(\mathrm{CA})$ are formed at a molar ratio of 1:1. One can see that in this case the content of calcium ( $\mathrm{Ca}$ ) is higher than given by the experimental data. The overestimated calcium amount suggests that $\mathrm{CA}$ and HAP may precipitate with calcium deficiency. Therefore, case 2 shows $\mathrm{CA}$ and HAP with deficiency of calcium in the forms: $\mathrm{Ca}_{10-x}\left(\mathrm{PO}_{4}\right)_{6}(\mathrm{OH})_{2}$ and $\mathrm{Ca}_{10-x}\left(\mathrm{PO}_{4}\right)_{6} \mathrm{CO}_{3}$ (where $x=2$ and means that $\mathrm{Ca}^{2+}$ ion deficiency is compensated by $4 \mathrm{Na}^{+}$ions incorporated into the structure of CA and HAP). It is assumed that these two compounds are formed at a molar ratio of 1:1. In this case, the contents of calcium, oxygen, and phosphorus are consistent with the experimental EDX results. However, it should be noted that the EDX results do not confirm the presence of sodium, although the presence of $\mathrm{Na}^{+}$in the CA and HAP structure was confirmed by the XRD method (Figure 3b).

In case 3, it was assumed that $\mathrm{Cl}^{-}$ion is introduced instead of $\mathrm{OH}^{-}$or $\mathrm{CO}_{3}{ }^{2-}$ group. In such a way one gets a mixture of three compounds: $\mathrm{Ca}_{10-x}\left(\mathrm{PO}_{4}\right)_{6}(\mathrm{OH})_{2}, \mathrm{Ca}_{10-x}\left(\mathrm{PO}_{4}\right)_{6} \mathrm{CO}_{3}$, and $\mathrm{Ca}_{10-x}\left(\mathrm{PO}_{4}\right)_{6} \mathrm{Cl}_{2}$ at a molar ratio of 1:1:1. However, it should be noted that if $\mathrm{OH}^{-}$and $\mathrm{CO}_{3}{ }^{2-}$ are actually replaced by $\mathrm{Cl}^{-}$ion, this is not the case for all molecules because the amount of $\mathrm{Cl}^{-}$is too high when compared with experimental results. Therefore, in case 4 it is assumed that a mixture of three compounds: $\mathrm{Ca}_{10-x}\left(\mathrm{PO}_{4}\right)_{6}(\mathrm{OH})_{2}, \mathrm{Ca}_{10-x}\left(\mathrm{PO}_{4}\right)_{6} \mathrm{CO}_{3}$, and $\mathrm{Ca}_{10-x}\left(\mathrm{PO}_{4}\right)_{6} \mathrm{Cl}_{2}$ is formed, however only $10 \%$ of mass of this sample is in the form of $\mathrm{Ca}_{10-x}\left(\mathrm{PO}_{4}\right)_{6} \mathrm{Cl}_{2}$. In this case, the amount of $\mathrm{Cl}$ agrees with the experiment.

As follows from the comparison of the calculations for the above four cases with the experimental values, the tested samples contain CA and HAP. However, part of the CA and HAP precipitates with calcium deficiency (case 2). In addition, some of the $\mathrm{OH}^{-}$groups and $\mathrm{CO}_{3}{ }^{2-}$ ions are replaced by $\mathrm{Cl}^{-}$ ion and thus chlorapatite $\left(\mathrm{Ca}_{10-x}\left(\mathrm{PO}_{4}\right)_{6} \mathrm{Cl}_{2}\right)$ is formed. These results are compatible with XRD results which show that non-stoichiometric HAP and/or CA may be formed. Non-stoichiometry lies in the fact that the respective ions, such as $\mathrm{Na}^{+}$or $\mathrm{Cl}^{-}$, substitute for the $\mathrm{Ca}^{2+}, \mathrm{OH}^{-}$groups and /or $\mathrm{CO}_{3}{ }^{2-}$ ions in HAP and / or CA.

It should also be taken into account that $\mathrm{CA}$ and HAP may exist in amorphous form as amorphous calcium carbonate (ACC) and amorphous calcium phosphate (ACP), respectively. The existence of amorphous carbonated calcium phosphate (ACCP) is also possible [24].

\section{Conclusions}

The results presented in this article demonstrate that CA, HAP and/or non-stoichiometric CA and HAP with different ion substitutions for $\mathrm{PO}_{4}{ }^{3-}, \mathrm{CO}_{3}{ }^{2-}$, and $\mathrm{OH}^{-}$groups are formed in the artificial urine of modified (without $\mathrm{Mg}^{2+}$ cations) and non-modified compositions. The results 
demonstrate also that non-stoichiometric CA and HAP can be formed with calcium deficit. In such a case, the XRD result indicates that calcium $\mathrm{Ca}^{2+}$ ions are replaced by sodium ions $\mathrm{Na}^{+}$. Specifically, the presence of chlorapatite, $\mathrm{Ca}_{10}\left(\mathrm{PO}_{4}\right)_{6} \mathrm{Cl}_{2}$, and calcium sodium phosphate carbonate hydroxide, $\mathrm{Ca}_{9} \mathrm{Na}_{0.5}\left(\mathrm{PO}_{4}\right)_{4.5}\left(\mathrm{CO}_{3}\right)_{1.5}(\mathrm{OH})_{2}$, is found. All of these compounds exhibit poor crystallinity. In addition, $\mathrm{XRD}$ and Raman results indicate the presence of amorphous phases. These may be amorphous calcium carbonate (ACC), amorphous calcium phosphate (ACP), and/or amorphous carbonated calcium phosphate (ACCP). It is suggested that the amorphous phases may exist as precursors of crystalline phases.

The theoretical speciation analysis shows that in the case of modified urine (without magnesium chloride hexahydrate) the amount of CA formed is much smaller than in the case of non-modified urine. In addition, in the case of non-modified urine, the formation of both CA and HAP is shifted towards lower $\mathrm{pH}$ values compared to the case for modified urine. In both cases, for the modified and non-modified urine, $\mathrm{CA}$ is formed first (at lower $\mathrm{pH}$ ) and then HAP (at higher $\mathrm{pH}$ ). Additionally the amount of $\mathrm{CA}$ is the dominant phase at low $\mathrm{pH}$, while HAP is the dominant phase at $\mathrm{pH}=9$. These conclusions, resulting from the theoretical speciation analysis, are also confirmed by the spectroscopic analysis. Differences in the formation of CA and HAP in modified and non-modified urine indicate that the presence of magnesium is crucial for the formation of these phases.

Acknowledgments: This work was partly supported by the National Science Centre (Poland), Grant No. DEC-2013/11/B/ST3/03871 and partly by the Ministry of Science and Higher Education (Poland), Grant No. I-3/501-17-3-1-727. Jolanta Prywer thanks the University of Florida, Department of Pathology, Immunology, and Laboratory Medicine for the computer program EQUIL.

Author Contributions: The contribution of Jolanta Prywer covered the formulation of the problem of article and its concept; preparation of samples without the presence of bacteria; analysis of XRD and EDX results; managing a research project covering research being a problem of article; writing the initial version of the article; participation in the interpretation of results and formulation of conclusions. Marcin Kozanecki performed Raman and IR measurements along with the physical interpretation of the results obtained; he participated in writing the article and formulating conclusions. Ewa Mielniczek-Brzóska performed theoretical chemical speciation analysis and compared the obtained results with experimental results (EDX); she participated in the formulation of conclusions. Agnieszka Torzewska prepared samples in the presence of bacteria and described the procedure for their preparation.

Conflicts of Interest: There are no conflicts of interest to declare.

\section{References}

1. Jung, T.; Sheng, T.; Choi, C.K.; Kim, W.; Wesson, J.A.; Ward, M.D. Probing Crystallization of Calcium Oxalate Monohydrate and the Role of Macromolecule Additives with in Situ Atomic Force Microscopy. Langmuir 2004, 20, 8587-8596. [CrossRef] [PubMed]

2. Benramdane, L.; Bouatia, M.; Idrissi, M.O.B.; Draoui, M. Infrared Analysis of Urinary Stones, Using a Single Reflection Accessory and a KBr Pellet Transmission. Spectrosc. Lett. 2008, 41, 72-80. [CrossRef]

3. Petrova, E.V.; Gvozdev, N.V.; Rashkovich, L.N. Growth and Dissolution of Calcium Oxalate Monohydrate (COM) Crystals. J. Optoelectron. Adv. Mater. 2004, 6, 261-268.

4. Bichler, K.H.; Eipper, E.; Naber, K.; Braun, V.; Zimmermann, R.; Lahme, S. Urinary infection stones. Int. J. Antimicrob. Agents 2002, 19, 488-498. [CrossRef]

5. Gleeson, M.J.; Griffith, D.P. Struvite calculi. Br. J. Urol. 1993, 71, 503-511. [CrossRef] [PubMed]

6. McLean, R.J.C.; Nickel, J.C.; Cheng, K.J.; Costerton, J.W. The ecology and pathogenicity of urease-producting bacteria in the urinary tract CRC. Crit. Rev. Microbiol. 1988, 16, 37-79. [CrossRef] [PubMed]

7. Grases, F.; Söhnel, O.; Vilacampa, A.I.; March, J.G. Phosphates precipitating from artificial urine and fine structure of phosphate renal calculi. Clin. Chim. Acta 1996, 244, 45-67. [CrossRef]

8. Prien, E.L.; Frondel, C. Studies in urolithiasis. I. The composition of urinary calculi. J. Urol. 1947, 57, 949-994. [CrossRef]

9. Murphy, B.T.; Pyrah, L.N. The composition, structure and mechanisms of the formation of urinary calculi. Br. J. Urol. 1962, 34, 129-185. [CrossRef] [PubMed] 
10. Leusmann, D.B. A classification of urinary calculi with respect to their composition and micromorphology. Scand. J. Urol. 1991, 25, 141-150. [CrossRef]

11. Wopenka, B.; Pasteris, J.D. A mineralogical perspective on the apatite in bone. Mater. Sci. Eng. C 2005, 25, 131-143. [CrossRef]

12. Olszynski, M.; Prywer, J.; Torzewska, A. Effect of Size and Shape of Nanosilver Particles on Struvite and Carbonate Apatite Precipitation. Cryst. Growth Des. 2015, 15, 3307-3320. [CrossRef]

13. Prywer, J.; Olszynski, M. Influence of disodium EDTA on the nucleation and growth of struvite and carbonate apatite. J. Cryst. Growth 2013, 375, 108-114. [CrossRef]

14. Prywer, J.; Olszynski, M.; Torzewska, A.; Mielniczek-Brzóska, E. Comparative in vitro studies on disodium EDTA effect with and without Proteus mirabilis on the crystallization of carbonate apatite and struvite. J. Cryst. Growth 2014, 395, 123-131. [CrossRef]

15. Prywer, J.; Sadowski, R.R.; Torzewska, A. Aggregation of Struvite, Carbonate Apatite, and Proteus mirabilis as a Key Factor of Infectious Urinary Stone Formation. Cryst. Growth Des. 2015, 15, 1446-1451. [CrossRef]

16. Prywer, J.; Olszynski, M.; Mielniczek-Brzóska, E. Inhibition of precipitation of carbonate apatite by trisodium citrate analysed in base of the formation of chemical complexes in growth solution. J. Solid State Chem. 2015, 231, 80-86. [CrossRef]

17. Prywer, J.; Mielniczek-Brzóska, E. Chemical equilibria of complexes in urine. A contribution to the physicochemistry of infectious urinary stone formation. Fluid Phase Equilib. 2016, 425, 282-288. [CrossRef]

18. Prywer, J.; Olszynski, M. Bacterially induced formation of infectious urinary stones: Recent developments and future challenges. Curr. Med. Chem. 2017, 24, 292-311. [CrossRef] [PubMed]

19. Torzewska, A.; Rozalski, A. Various intensity of Proteus mirabilis-induced crystallization resulting from the changes in the mineral composition of urine. ActaBiochim. Pol. 2015, 62, 127-132. [CrossRef]

20. Griffith, D.P.; Musher, D.M.; Itin, C. Urease. The primary cause of infection-induced urinary stones. Investig. Urol. 1976, 13, 346-350.

21. Omar, N.B.; Martinez-Canamero, M.; Gonzales-Munoz, T.; Arias, J.M.; Huertas, F. Myxococcusxantus killed cells as inducers of struvite crystallization. Its possible role in the biomineralization processes. Chemosphere 1995, 30, 2387-2396. [CrossRef]

22. Lerner, S.P.; Gleeson, M.J.; Griffith, D.P. Infection stones. J. Urol. 1989, 141, 753-758. [CrossRef]

23. Kramer, G.; Klinger, H.C.; Steiner, G.E. Role of bacteria in the development of kidney stones. Curr. Opin. Urol. 2000, 10, 35-38. [CrossRef] [PubMed]

24. Carpentier, X.; Daudon, M.; Traxer, O.; Jungers, P.; Mazouyes, A.; Matzen, G.; Véron, E.; Bazin, D. Relationships Between Carbonation Rate of Carbapatite and Morphologic Characteristics of Calcium Phosphate Stones and Etiology. Urology 2009, 73, 968-975. [CrossRef] [PubMed]

25. Rottschaefer, B.L.; Sax, M.; Pletcher, J.; Braude, A.I. Transition of Amorphous Magnesium Ammonium Phosphate to a Crystalline State in Rat Urinary Calculi Induced by L-Forms of Proteus mirabilis. Calcif. Tissue Res. 1970, 5, 80-84. [CrossRef] [PubMed]

26. Garrigues, S.; de la Guardia, M. Direct Determination Methods without Sample Preparation. In Challenges in Green Analytical Chemistry; de la Guardia, M., Garrigues, S., Eds.; Royal Society of Chemistry: London, UK, 2011; Chapter 2.

27. Martin-Neto, L.; Milori, D.M.B.P.; da Silva, W.T.L.; Simões, M.L. EPR, FTIR, Raman, UV-visible Absorption and Fluorescence Spectroscopies in Studies of NOM. In Biophysico-Chemical Processes Involving Natural Nonliving Organic Matter in Environmental Systems; Senesi, N., Xing, B., Huang, P.M., Eds.; John Wiley \& Sons: Hoboken, NJ, USA, 2009; Chapter 16.

28. Alderighi, L.; Gans, P.; Ienco, A.; Peters, D.; Sabatini, A.; Vacca, A. Hyperquad simulation and speciation (HySS): A utility program for the investigation of equilibria involving soluble and partially soluble species. Coord. Chem. Rev. 1999, 184, 311-318. [CrossRef]

29. Brown, C.M.; Ackermann, D.K.; Purich, D.L. EQUIL 93: A tool for experimental and clinical urolithiasis. Urol. Res. 1994, 22, 119-126. [CrossRef] [PubMed]

30. Lin, Y.; Singer, P.C. Inhibition of calcite precipitation by orthophosphate: Speciation and thermodynamic considerations. Geochim. Cosmochim. Acta 2006, 70, 2530-2539. [CrossRef]

31. Bengtsson, Å.; Lindegren, A.; Sjöoberg, S.; Persson, P. Dissolution, adsorption and phase transformation in the fluorapatite e goethite system. Appl. Geochem. 2007, 22, 2016-2028. [CrossRef] 
32. Stefánsson, A.; Bénézeth, J.; Schott, J. Potentiometric and spectrophotometric study of the stability of magnesium carbonate and bicarbonate ion pairs to $150{ }^{\circ} \mathrm{C}$ and aqueous inorganic carbon speciation and magnesite solubility. Geochim. Cosmochim. Acta 2014, 138, 21-31. [CrossRef]

33. Prywer, J.; Torzewska, A.; Płociński, T. Unique Surface and Internal Structure of Struvite Crystals Formed by Proteus mirabilis. Urol. Res. 2012, 40, 699-707. [CrossRef] [PubMed]

34. Chen, L.; Shen, Y.; Xie, A.; Huang, F.; Zhang, W.; Liu, S. Seed-Mediated Synthesis of Unusual Struvite Hierarchical Superstructures Using Bacterium. Cryst. Growth Des. 2010, 10, 2073-2082. [CrossRef]

35. Cölfen, H. Single Crystals with Complex Form via Amorphous Precursors. Angew. Chem. Int. Ed. 2008, 47, 2351-2353. [CrossRef] [PubMed]

36. LeGeros, R.Z.; Trautz, O.R.; LeGeros, J.P.; Klein, E.; Shirra, W.P. Apatite Crystallites: Effects of Carbonate on Morphology. Science 1967, 155, 1409-1411. [CrossRef] [PubMed]

37. El Feki, H.; Savariault, J.M.; Abdelhamid, B.S. Structure refinements by the Rietveld method of partially substituted hydroxyapatite: $\mathrm{Ca}_{9} \mathrm{Na}_{0.5}(\mathrm{PO} 4)_{4.5}\left(\mathrm{CO}_{3}\right)_{1.5}(\mathrm{OH})_{2}$. J. Alloys Compd. 1999, 287, 114-120. [CrossRef]

38. Kubala-Kukuś, A.; Arabski, M.; Stabrawa, I.; Banaś, D.; Różański, W.; Lipiński, M.; Majewska, U.; Wudarczyk-Moćko, J.; Braziewicz, J.; Pajek, M.; et al. Application of TXRF and XRPD techniques for analysis of elemental and chemical composition of human kidney stones. X-ray Spectrom. 2017, 46, 412-420. [CrossRef]

39. Tsuji, T.; Onuma, K.; Yamamoto, A.; Iijima, M.; Shiba, K. Direct transformation from amorphous to crystalline calcium phosphate facilitated by motif-programmed artificial proteins. Proc. Natl. Acad. Sci. USA 2008, 105, 16866-16870. [CrossRef] [PubMed]

40. Weiner, S.; Sagi, I.; Addadi, L. Structural biology. Choosing the crystallization path less traveled. Science 2005, 309, 1027-1028. [CrossRef] [PubMed]

41. Weiner, S.; Mahamid, J.; Politi, Y.; Ma, Y.; Addadi, L. Overview of the amorphous precursor phase strategy in biomineralization. Front. Mater. Sci. China 2009, 3, 104-108. [CrossRef]

42. Chen, H.; Zheng, X.; Li, Q.; Yang, Y.; Xiao, S.; Hu, C.; Bai, Y.; Zhang, T.; Wong, K.S.; Yang, S. An amorphous precursor route to the conformable oriented crystallization of $\mathrm{CH}_{3} \mathrm{NH}_{3} \mathrm{PbBr}_{3}$ in mesoporous scaffolds: Toward efficient and thermally stable carbon-based perovskite solar cells. J. Mater. Chem. A 2016, 4, 12897-12912. [CrossRef]

43. Fratzl, P.; Fischer, F.D.; Svoboda, J.; Aizenberg, J. A kinetic model of the transformation of a micropatterned amorphous precursor into a porous single crystal. Acta Biomater. 2010, 6, 1001-1005. [CrossRef] [PubMed]

44. Eanes, E.D.; Posner, A.S. Intermediate phases in the basic solution preparation of alkaline earth phosphates. Calcif. Tissue Res. 1968, 2, 38-48. [CrossRef] [PubMed]

45. Markovic, M.; Fowler, B.O.; Tung, M.S. Preparation and Comprehensive Characterization of a Calcium Hydroxyapatite Reference Material. J. Res. Natl. Inst. Stand. Technol. 2004, 109, 553-568. [CrossRef] [PubMed]

46. RRUFF ${ }^{\mathrm{TM}}$ Database. Available online: http:// rruff.info (accessed on 1 July 2018).

47. Santos, R.V.; Clayton, R.N. The carbonate content in high-temperature apatite: An analytical method applied to apatite from the Jacupiranga alkaline complex. Am. Mineral. 1995, 80, 336-344. [CrossRef]

48. Bigi, A.; Falini, G.; Foresti, E.; Gazzano, M.; Ripamonti, A.; Roved, N. Magnesium influence on hydroxyapatite crystallization. J. Inorg. Biochem. 1993, 49, 69-78. [CrossRef]

49. Nancollas, G.H.; Tomazic, B.; Tomson, M. The precipitation of calcium phosphates in the presence of magnesium. Croat. Chem. Acta 1976, 48, 431-438.

50. Salimi, M.H.; Heughebaert, J.C.; Nancollas, G.H. Crystal growth of calcium phosphates in the presence of magnesium ions. Langmuir 1985, 1, 119-122. [CrossRef]

51. Amjad, Z.; Koutsoukos, P.G.; Nancollas, G.H. The crystallization of hydroxyapatite and fluorapatite in the presence of magnesium ions. J. Colloid Interface Sci. 1984, 101, 250-256. [CrossRef]

(C) 2018 by the authors. Licensee MDPI, Basel, Switzerland. This article is an open access article distributed under the terms and conditions of the Creative Commons Attribution (CC BY) license (http:/ / creativecommons.org/licenses/by/4.0/). 